ISSN $2527-5542$
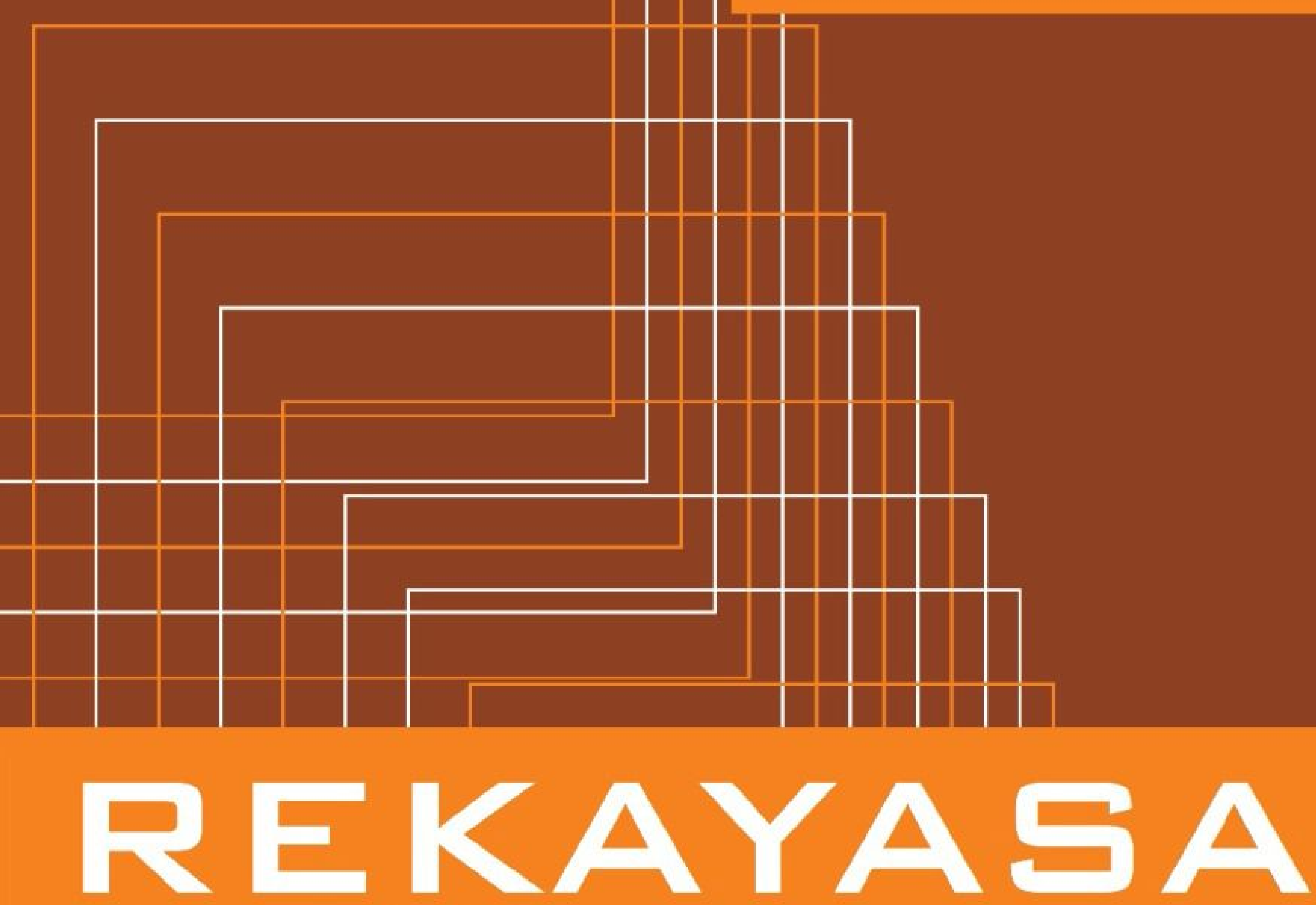
JURNAL TEKNIK SIPIL 


\section{REKAYASA TEKNIK SIPIL}

Media Publikasi Karya Ilmiah di Bidang Teknik Sipil

Volume 5, Nomer 1.

Juni 2020

\section{Penanggung Jawab :}

Ir. Moch. Hazin Mukti, MT., MM

\section{Mitra Bestari :}

Prof. Dr. Ir. Lalu Mulyadi, MT

Dr. Ir. Kustamar, MT

Dr. Faisal Estu Yulianto, ST., MT.

Dr. Gusfan Khalik, ST., MT.

\section{Komite Pelaksana :}

Dedy Asmaroni, ST., MT.

Taurina Jemmy Irwanto, ST., MT.

Ahmad Fatoni ST., MT.

Aldi Setiawan, ST.,MT.

Ahmad Fausi, ST.

Komite Pelaksana :

Fakultas Teknik - Universitas Madura

Jl. Raya Panglegur KM. 3,5 Pamekasan 69317

Telp. (0324) 322231 psw 114 Fax (0324) 327418

Email : Jurnal.rekayasa.unira@gmail.com 


\section{REKAYASA TEKNIK SIPIL}

Media Publikasi Karya Ilmiah di Bidang Teknik Sipil

Volume 5, Nomer 1.

Juni 2020

\section{DAFTAR ISI}

1. Analisis Kepuasan Penumpang Kereta Api Terhadap Angkutan Umum di Stasiun Madiun

Arinda Leliana, Blima Oktaviastuti

2. Pengaruh Bahan Tambah Serbuk Ban Bekas Pada Konstruksi Hotrolled Sheet-Wearing Course

Blima Oktaviastuti, Arinda Leliana, Luthfil Abid

3. Evaluasi Kinerja Sistem Manajemen Keselamatan dan Kesehatan Kerja (SMK3) Pada Proyek Attic Showroom dan East Coast Center 2 Di Surabaya

Juliandres Unitly, Feri Harianto, Dian Listyaningsih

4. Pengaruh Penerapan Keselamatan Dan Kesehatan Kerja (K3) Serta Lingkungan Kerja Terhadap Produktivitas Kerja Di Surabaya Ahmad Zainul Arifin ,Feri Harianto

5. Analisa Kualitas Pekerjaan Dinding Dengan Bata Merah dan Bata Ringan (Studi Kasus : Perumahan Type 46 Di Kabupaten Pamekasan)

Dedy Asmaroni ,Ach. Rofii 


\title{
Analisis Kepuasan Penumpang Kereta Api Terhadap Angkutan Umum di Stasiun Madiun
}

\author{
Arinda Leliana ${ }^{1}$ dan Blima Oktaviastuti ${ }^{2}$ \\ ${ }^{1}$ Program Studi Manajemen Transportasi Perkeretaapian, Politeknik Perkeretaapian Indonesia, Madiun \\ ${ }^{2}$ Jurusan Teknik Sipil, Fakultas Teknik, Universitas Tribhuwana Tunggadewi, Malang \\ E-mail: $\underline{\text { arindaleliana21@gmail.com, blima.oktavia90@gmail.com }}$
}

\begin{abstract}
ABSTRAK: Sistem pelayanan angkutan umum yang ada di Kota Madiun yaitu menggunakan sistem jaringan trayek. Meskipun demikian pelayanan angkutan umum yang dirasakan penumpang di stasiun Madiun kurang, seperti dalam hal waktu tunggu angkutan umum yang lama, ketersediaan jumlah armada yang sedikit, kenyamanan dalam angkutan umum, dan masih banyak lagi. Oleh karean itu perlu adanya penelitian mengenai seberapa besar kepuasan serta harapan penumpang angkutan umum di stasiun Madiun mengenai kinerja angkutan umum di stasiun Madiun. Studi ini bertujuan untuk mengetahui karakteristik apa saja yang menjadi pertimbangan kepuasan terhadap angkutan umum di stasiun Madiun. Analisis data hasil dari kuesioner diolah menggunakan analisis kuadran dengan menggunakan metode Importance Performance Analysis (IPA) dan metode Customer Satisfaction Index (CSI). Analisis hasil data menunjukan tingkat kepuasan dan harapan sebesar 0,62 yang berarti penumpang cukup puas dengan kinerja angkutan umum di stasiun Madiun. Masih terdapat beberapa atribut yang kinerja pelayanannya kurang antara lain perlunya jam operasional angkutan umum yang jelas, waktu tunggu angkutan umum yang lama, informasi lokasi serta petunjuk arah angkutan lanjutan yang masih belum ada dan sangat diperlukan. Kondisi armada angkutan umum yang beroperasi banyak yang sudah lama, maka perlu adaya peremajaan armada.
\end{abstract}

Kata Kunci : Kinerja pelayanan, Angkutan umum, Analisa kuadran

\section{PENDAHULUAN}

Stasiun Madiun merupakan stasiun besar wilayah Daop 7 Madiun dan menjadi tempat naik turunnya penumpang untuk semua kelas kereta api, baik kereta api kelas ekonomi maupun kelas eksekutif. Kegiatan perkeretaapian di stasiun madiun berlangsung selama 24 jam untuk mengakomodir pergerakan penumpang yang datang dan pergi. Angkutan intermoda yang terdapat di stasiun besar Madiun meliputi angkutan umum penumpang/angkot dan angkutan umum lainnya seperti taksi, ojek, dan becak. Namun sebagian besar penumpang kereta api masih menggunakan kendaraan pribadi untuk dari atau menuju stasiun Madiun, dengan alasan lebih cepat, lebih murah dan lebih efisien waktu.

Penumpang di stasiun Madiun yang saat ini menggunakan angkutan umum untuk perpindahan modanya sangatlah sedikit. Terdapat 2 rute trayek angkutan umum yang melintasi stasiun Madiun yaitu Line D dan Line C. Sistem pelayanan angkutan umum yang ada di stasiun Madiun menggunakan sistem jaringan trayek. Beberapa permasalahan yang muncul antara lain waktu tunggu angkutan umum lama, banyak angkutan umum sering ngetem sembarang tempat dan lama, angkutan umum yang melewati stasiun Madiun hanya di jam-jam tertentu yaitu pukul 06.00 pagi waktu orang berangkat kerja dan sekolah, pukul 13.00 siang, dan pukul 17.00 sore waktu orang pulang kerja dan sekolah. Jam operasional tersebut terbatas dikarenakan sepi penumpang di stasiun, selain itu juga jumlah armada yang beropersi juga sedikit. Karena tidak ada penumpang yang menggunakan jasa angkutan umum maka angkutan umum pun tidak beroperasi dengan trayek yang semestinya. Ditambah dengan angkutan online yang sekarang jauh lebih mudah efektif dan efisien maka kedepan mungkin angkutan umum akan semakin tersingkirkan.
Penumpang yang naik dan turun dari stasiun Madiun hanya satu atau dua penumpang saja yang menggunakan angkutan umum penumpang/angkot untuk perpindahan modanya. Banyak penumpang yang tidak mengetahui trayek rute nya bahkan tarifnya, untuk menunggu angkot datang pun lama. Selain itu menurut para penumpang bila naik angkot waktu tempuh jauh lebih lama dan lama perjalanan tidak dapat diperkirakan karena angkot banyak yang sering ngetem sehingga penumpang takut ketinggalan kereta. Ketidakpastian waktu yang harus ditempuh oleh penumpang angkutan umum saat melakukan perjalanan dengan angkutan umum, sehingga menimbulkan rasa tidak puas atau kecewa. Minimnya informasi mengenai angkutan umum pun menjadi masalah. Di stasiun belum ada papan informasi mengenai rute, jadwal tentang angkutan umum.

Dengan latar belakang permasalahan tersebut maka perlu adanya analisis mengenai kinerja dan harapan penumpang terhadap angkutan umum di stasiun Madiun. Karakteristik apa saja yang menjadi pertimbangan kepuasan atau ketidakpuasan terhadap pelayanan angkutan umum di stasiun Madiun. Sasaran penelitian ini adalah untuk mengetahui nilai Customer Satisfaction Index (CSI) melalui perhitungan nilai kinerja dan tingkat kepentingan pengguna jasa terhadap pelayanan di stasiun Madiun dengan metode (IPA) Importance Performance Analysis menggunakan analisa kuadran atau diagram kartesius. Hasil dari penilaian tingkat kepuasan pengguna angkutan umum ini akan sangat membantu pemerintah kabupaten Madiun dalam penyelenggaraan dan pengoperasian serta dapat meningkatkan atau mempertahankan kualitas pelayanan yang lebih baik.

\section{METODE}

Penelitian ini termasuk dalam analisis data deskriptif kuantitatif. Dalam penelitan ini terdapat 2 rute trayek yaitu Line D dan Line C. Sampel dipilih secara acak (random 
sampel) dimana sampel merupakan penumpang di stasiun Madiun. Pengumpulan data dilakukan melalui interview maupun wawancara terstruktur dengan menggunakan kuesioner dan angket. Pengumpulan data dilakukan melalui penyebaran kuesioner pada saat hari kerja.

Terlebih dahulu dilakukan survey pendahuluan untuk mengevaluasi kuesioner dan dilakukan uji validitas dan uji reliabilitas instrumen sehingga dapat diketahui apakah setiap butir pertanyaan tersebut valid dan reliable. Data yang sudah terkumpul dianalisis menggunakan diagram kartesius dengan metode Importance Performance Analysis (IPA) serta metode Customer Satisfaction Index (CSI). Untuk mengukur persepsi kepentingan dan harapan responden dalam hal ini atribut layanan mengenai kinerja dan harapan dengan menggunakan skala likert mulai dari 5 dengan nilai sangat baik, 4 dengan nilai baik, 3 dengan nilai cukup baik, 2 dengan nilai kurang baik, dan 1 dengan nilai tidak baik (Sugiyono, 2017).

\section{PEMBAHASAN}

\section{1) Uji Validitas dan Uji Reliabilitas}

Uji validitas dilakukan terhadap kuesioner yang berkaitan dengan kondisi kenyataan dan kondisi harapan penumpang. Uji validitas dimaksudkan untuk menguji apakah instrumen pertanyaan dalam kuesioner tersebut valid untuk mendapatkan jawaban responden. Semakin tinggi koefisien validitas maka semakin baik instrumen tersebut dan dikatakan valid jika hasilnya sesuai dengan kriteria, serta dapat memberikan gambaran yang cermat sesuai dengan maksud dilakukan pengukuran.

Untuk mengetahui kelayakan butir-butir pertanyaan kuesioner dalam mendefinisikan suatu variabel maka dilakukan uji validitas. Untuk mengetahui kriteria yang digunakan dalam menilai hasil uji validitas yaitu nilai korelasi (r) yang disebut dengan koefisien validitas. Nilai $r$ hasil perhitungan dibandingkan dengan nilai $r$ tabel dimana apabila nilai $r$ tabel lebih kecil dari pada nilai $r$ hitung maka butir pertanyaan tersebut diaanggap valid (Nurhidayat dkk, 2017). Instrumen terdiri atas 12 atribut pertanyaanatau pernyataan. Dimana tiap atribut disiapkan 5 interval jawaban, jawaban terendah maka diberi skor 1 dan tertinggi akan diberi skor 5. Instrumen yang valid berarti alat ukur yang digunakan dalam mendapatkan data (mengukur) itu valid, berarti instrumen yang digunakan tersebut dapat mengukur apa yang seharusnya diukur. Hasil uji validitas kinerja angkutan umum terdapat pada Tabel 1 .

Tabel 1 Uji Validitas Kinerja Angkutan Umum

\begin{tabular}{|c|c|c|c|c|}
\hline Atribut & $\begin{array}{c}\text { Besaran } \mathrm{r} \\
\text { kenyataan }\end{array}$ & $\begin{array}{c}\text { Besaran } \mathrm{r} \\
\text { harapan }\end{array}$ & $\mathrm{r}$ tabel & Ket \\
\hline P1 & 0,65 & 0,32 & 0,14 & Valid \\
P2 & 0,74 & 0,37 & 0,14 & Valid \\
P3 & 0,81 & 0,37 & 0,14 & Valid \\
P4 & 8,90 & 0,33 & 0,14 & Valid \\
P5 & 0,74 & 0,36 & 0,14 & Valid \\
P6 & 0,81 & 0,37 & 0,14 & Valid \\
P7 & 0,93 & 0,37 & 0,14 & Valid \\
P8 & 0,87 & 0,36 & 0,14 & Valid \\
P9 & 1,16 & 0,38 & 0,14 & Valid \\
P10 & 0,93 & 0,33 & 0,14 & Valid \\
P11 & 0,97 & 0,37 & 0,14 & Valid \\
P12 & 1,01 & 0,35 & 0,14 & Valid \\
\hline
\end{tabular}

Apabila korelasi besaran $\mathrm{r}$ sama dengan 0,14 atau lebih (paling kecil 0,14), maka atribut dinyatakan valid. Tabel 1 dapat diketahui ternyata korelasi besaran $r$ semua atribut dengan $r$ tabel lebih dari 0,14 sehingga semua atribut intermoda valid. Atribut yang menunjukan validitas kategori yang tinggi untuk besaran $r$ kenyataan adalah atribut no 9 dengan besaran 1,16 dan atribut yang menunjukan validitas kategori yang rendah adalah atribut no 1 dengan besaran 0,65 . Untuk atribut yang menunjukan validitas kategori yang tinggi untuk besaran $r$ harapan adalah atribut no 9 dengan besaran 0,38 dan atribut yang menunjukan validitas kategori yang rendah adalah atribut no 1 dengan besaran 0,32. Bila besaran $r$ kenyataan dan $r$ harapan di bawah 0,14 maka atribut instrumen tersebut tidak valid sehingga perlu diperbaiki atau dibuang.

Uji reliabilitas, Semakin tinggi nilai koefisien $\alpha$ berkisar 0-1 atau semakin mendekati nilai satu (1), maka semakin tinggi pula tingkat reliabilitasnya. Sehingga memenuhi syarat dalam melakukan analisa lebih lanjut. Nilai reliabilitas yang baik adalah diatas 0,8 sedangkan nilai 0,7 masih bia diterima, namun nilai dibawah 0,6 diangggap buruk.

Reliabilitas memberikan gambaran sejauh mana suatu hasil pengukuran dapat dipercaya yang berarti sejauh mana skor hasil pengukuran terbebas dari kesalahan pengukuran. Uji reliabilitas atau kehandalan merupakan ukuran kestabilan dan konsistensi responden dalam menjawab butir-butir pertanyaan yang berkaitan dengan dimensi variabel penelitian yang terdapat pada Tabel 2 .

Tabel 2 Uji Reliabilitas Kinerja Angkutan Umum

\begin{tabular}{|c|c|c|c|c|}
\hline Atribut & $\begin{array}{c}\text { Besaran } \mathrm{r} \\
\text { kenyataan }\end{array}$ & $\begin{array}{c}\text { Besaran } \mathrm{r} \\
\text { harapan }\end{array}$ & $\begin{array}{c}\mathrm{r} \\
\text { tabel }\end{array}$ & Ket \\
\hline P1 & 0,65 & 0,32 & 0,14 & Reliabel \\
P2 & 0,74 & 0,37 & 0,14 & Reliabel \\
P3 & 0,81 & 0,37 & 0,14 & Reliabel \\
P4 & 8,90 & 0,33 & 0,14 & Reliabel \\
P5 & 0,74 & 0,36 & 0,14 & Reliabel \\
P6 & 0,81 & 0,37 & 0,14 & Reliabel \\
P7 & 0,93 & 0,37 & 0,14 & Reliabel \\
P8 & 0,87 & 0,36 & 0,14 & Reliabel \\
P9 & 1,16 & 0,38 & 0,14 & Reliabel \\
P10 & 0,93 & 0,33 & 0,14 & Reliabel \\
P11 & 0,97 & 0,37 & 0,14 & Reliabel \\
P12 & 1,01 & 0,35 & 0,14 & Reliabel \\
\hline \multicolumn{5}{|r|}{} \\
\hline
\end{tabular}

Dari hasil pengujian dapat pada Tabel 2 diketahui besaran $r$ hitung kenyataan dan besaran $r$ hitung harapan lebih besar dari $r$ tabel yaitu 0,14 sehingga dapat disimpulkan bahwa kuesioner tersebut valid dan dapat digunakan untuk uji yang selanjutnya. Korelasi besaran $r$ kenyataan rata-rata sebesar 0,86 dan besaran $r$ harapan rata-rata sebesar 0,94 nilai reliabilitasnya baik karena mendekati 1.

\section{2) Analisis Tingkat Kinerja Dan Harapan}

Penilaian tingkat kepuasan penumpang kereta api terhadap angkutan umum di stasiun Madiun digunakan sebagai indikator perbaikan untuk kedepannya agar selalu memperhatikan apa yang diinginkan penumpang. Penilaian tingkat kepuasan penumpang terhadap intermoda di stasiun Madiun terdiri dari 12 atribut 
pertanyaan. Pelayanan harapan berdasarkan layanan yang diterima oleh penumpang terhadap angkutan umum sangat bervariasi dan penumpang rata-rata sangat berharap terhadap perbaikan kinerja dan layanan angkutan umum di stasiun madiun.

Data instrumen penelitian berupa kuesioner berisi pertanyaan yang mengukur kepuasan dan harapan. Kuesioner yang diformulasikan dalam pertanyaan dimana semua item pertanyaan yang akan diajukan dikelompokkan menjadi 6 dimensi kualitas pelayanan yang meliputi; keandalan (reliabillity), ketanggapan (responsivenes), jaminan kenyamanan (assurance), empati perhatian (emphety), berwujud nyata (tangible), aksesibilitas kemudahan (accessibillity). Berikut pada Tabel 3 perhitungan nilai rata-rata tingkat kinerja serta harapan penumpang angkutan umum di stasiun Madiun.

Tabel 3 Faktor-faktor Kepuasan Penumpang Angkutan Umum Di Stasiun Madiun

\begin{tabular}{|c|c|c|c|}
\hline Atribut & $\begin{array}{c}\text { Kenyataan } \\
\bar{X}\end{array}$ & Harapan $\bar{Y}$ & $\begin{array}{c}\text { Tingkat } \\
\text { kesesuaian } \%\end{array}$ \\
\hline P1 & 3,28 & 4,35 & 75,45 \\
P2 & 3,11 & 4,33 & 71,86 \\
P3 & 3,07 & 4,29 & 70,33 \\
P4 & 3,01 & 4,36 & 71,53 \\
P5 & 3,12 & 4,32 & 73,48 \\
P6 & 3,18 & 4,38 & 69,44 \\
P7 & 3,04 & 4,42 & 68.90 \\
P8 & 2,90 & 4,41 & 65,75 \\
P9 & 2,99 & 4,41 & 67.66 \\
P10 & 3,07 & 4,43 & 69.22 \\
P11 & 3,20 & 4,42 & 72.42 \\
P12 & 3,14 & 4,44 & 70.71 \\
\hline Rata-rata & 3,09 & 4,38 & 70,56 \\
\hline
\end{tabular}

Presentase tingkat kesesuaian $80-100 \%$ yang berarti kinerja dari masing-masing atribut telah memenuhi harapan dari penumpang namun masih perlu dilakukan beberapa perbaikan. Apabila presentase tingkat kesesuaian atribut $>100 \%$ maka kinerja atribut tersebut telah melebihi dengan harapan penumpang (Lodhita dkk, 2014). Hasil analisis menunjukan ada beberapa atribut yang tingkat kesesuaiannya kurang memenuhi harapan dari penumpang.

\section{3) Analisis Kuadran}

Analisis kuadran adalah analisis deskriptif yang pertama kali disampaikan pada tahun 1977 oleh John A. Martilla dan John James atau juga disebut sebagai Important Performance Analysis (IPA) (Martilla dkk, 1977). Hasil perhitungan mengenai tingkat kinerja dan harapan kemudian dijabarkan dalam empat kuadran atau kuadran diagram kartesius. Penjabaran ini dimaksudkan agar memperoleh titik-titik pembagian pada diagram tersebut berdasarkan tingkat kinerja serta kepentingan yang selanjutnya dikelompokkan dan diprioritaskan upaya perbaikan terhadap faktor atau atribut yang dianggap penting dan diharapkan penumpang untuk memperoleh kepuasan yang maksimal. Martilla and James (1977) membagi masing-masing menjadi 4 kuadran

- Kuadran I (High Importance/Low Performance) diberi label Concentrate Here
- Kuadran II (High Irnportancel High Performance) diberi label Keep up the good work

- Kuadran III (Low Importantance/Low Performance) diberi label Low Priority

- Kuadran IV (Low Importance/High Performance) diberi label sebagai Kemungkinan Overkill

Importance Performance Analysis (IPA) atau analisis kuadran merupaka alat bantu untuk menganalisis atau untuk membandingkan kinerja/pelayanan yang dapat dirasakan oleh pengguna jasa dibandingkan terhadap tingkat kepuasan yang diinginkan pengguna jasa. Importance Performance Analysis (IPA) mempunyai fungsi utama untuk menampilkan informasi tentang faktor-faktor pelayanan apa saja yang menurut konsumen sangat mempengaruhi kepuasan maupun loyalitasnya, dan faktor-faktor pelayanan apa saja yang menurut konsumen perlu diperbaiki karena belum memuaskan.

Untuk mengukur persepsi kepentingan dan kepuasan responden dalam hal atribut layanan mengenai kenyataan dan harapan dengan menggunakan skala likert mulai dari "sangat baik"(=5) sampai "tidak baik" $(=1)$ dan "sangat berharap"(=5) sampai “tidak berharap"(=1). Skala likert digunakan untuk mengukur sikap, pendapat, dan persepsi seseorang atau sekelompok orang mengenai fenomena sosial yang dimana jawaban setiap item instrumen mempunyai gradasi dari sangat positif sampai sangat negatif (Sugiyono, 2017).

Letak tiap atribut dalam diagram kartesius pada keempat kuadran tersebut dijadikan sebagai alternatif strategi untuk meningkatkan kepuasan penumpang selain itu juga menunjukan atribut apa saja yang mempengaruhi kepuasan penumpang terhadap intermoda di stasiun Madiun. Untuk ploting data masing-masing atribut dilakukan dengan menentukan sumbu rata-rata ${ }^{-} \mathrm{X}$ dan sumbu rata-rata ${ }^{-} \mathrm{Y}$. Di mana sumbu ${ }^{-} \mathrm{X}$ merupakan nilai rata-rata tingkat kepuasan $(3,1)$ dan sumbu ${ }^{-} \mathrm{Y}$ merupakan nilai rata-rata tingkat harapan $(4,4)$. Peta pada Gambar 1 posisi importance-performance merupakan suatu bangun yang dibagi menjadi empat kuadran dibatasi oleh dua buah garis berpotongan tegak lurus.

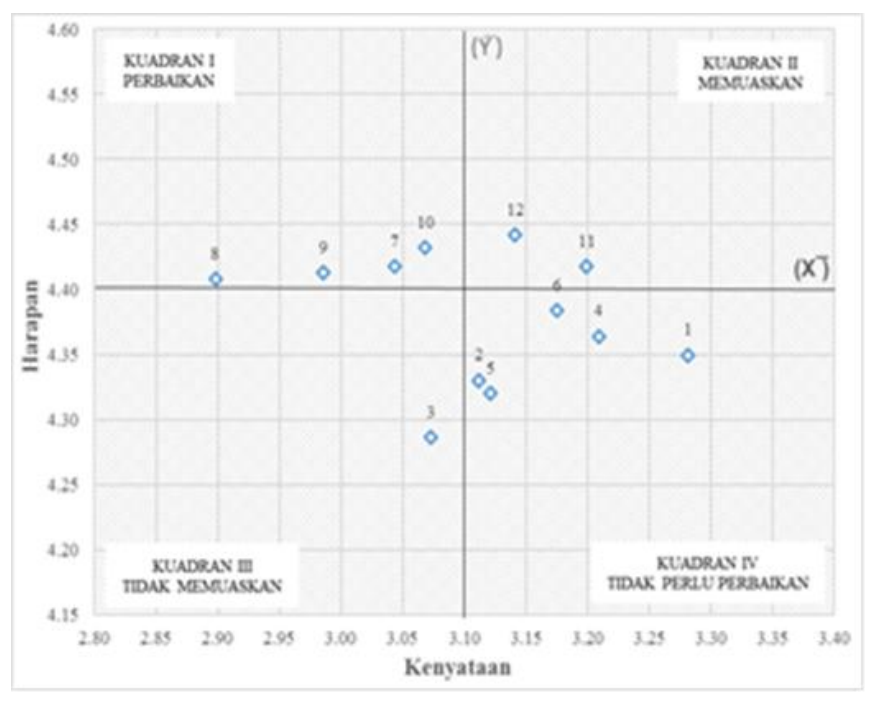

Gambar 1. Contoh gambar 
Pada Gambar 1 atribut untuk masing-masing kuadran adalah sebagai berikut:

- Kuadran I, Prioritas utama yang memerlukan perbaikan

Kuadran I menunjukan atribut yang memiliki kinerja rendah namun harapan yang diinginkan konsumen sangat tinggi. Atribut yang menjadi prioritas utama dan harus dilaksanakan sesuai harapan. Atribut yang termasuk dalam kuadran I tersebut meliputi:

$>$ Atribut 7 yaitu informasi lokasi dan petunjuk arah angkutan lanjutan mudah terlihat dan jelas untuk terbaca

$>$ Atribut 8 yaitu jam operasional angkutan umum

$>$ Atribut 9 yaitu tersedia informasi jadwal, rute angkutan umum lanjutan

$>$ Atribut 10 yaitu kondisi angkutan umum baik, bersih, terawat

Perlu adanya upaya agar dilakukan peremajaan armada serta penambahan fasilitas seperti AC agar menarik minat penumpang di stasiun Madiun untuk naik angkutan umum.

- Kuadran II, Pertahankan prestasi atau cukup memuaskan

Atribut yang berada di kuadran II merupakan atribut yang memiliki kinerja dan harapan sesuai dengan keinginan penumpang. Atribut yang ada merupakan atribut tang harus dipertahankan. Atribut dalam kuadran II tersebut meliputi:

$>$ Atribut 11 yaitu stasiun mudah diakses dengan menggunakan angkutan umum

$>$ Atribut 12 yaitu kemudahan mendapatkan angkutan umum lanjutan

3) Kuadran III, Prioritas rendah (tidak memuaskan) Atribut yang berada di kuadran III merupakan atribut yang memiliki kinerja yang rendah dan harapan dari penumpang juga rendah. Atribut yang ada merupakan atribut yang tidak terlalu diprioritaskan. Atribut yang termasuk dalam kuadran III tersebut meliputi:

> Atribut 3 yaitu waktu tunggu angkutan umum lanjutan cepat

> Atribut 4 yaitu waktu tempuh menuju tujuan cepat dengan menggunakan angkutan umum

$>$ Atribut 5 yaitu keamanan dan kenyamanan saat berpindah angkutan umum di stasiun

$>$ Atribut 6 yaitu keamanan di dalam angkutan umum

4) Kuadran IV, Berlebihan (tidak perlu perbaikan) Atribut di kuadran IV merupakan aatribut yang telah memiliki kinerja yang tinggi namun harapan dari penumpang tidak tinggi. Atribut yang ada merupakan atribut yang berlebihan. Atribut dalam kuadran IV tersebut meliputi:

$>$ Atribut 1 yaitu kecepatan angkutan umum, baik menuju stasiun maupun meninggalkan stasiun

$>$ Atribut 2 yaitu terdapat layanan angkutan umum lanjutan setelah turun dari stasiun.

\section{4) Analisis Kepuasan Customer Satisfaction Index (CSI) \\ Pengukuran terhadap indeks kepuasan}

penumpang dapat digunakan sebagai acuan untuk menentukan sasaran pengukuran kepuasan. Manfaat dilakukannya Customer Satisfaction Index untuk mengetahui seberapa besar tingkat kepuasan pengguna jasa angkutan umum khususnya penumpang di stasiun Madiun. Dengan indikator nilai CSI memepertimbangkan tingkat harapan pengguna jasa terhadap faktor yang akan ditentukan (Nurhidayat dkk, 2017). Indeks kepuasan pelanggan Customer statisfaction index (CSI) diukur dengan: menentukan rata-rata skor pentingnya, membuat faktor tertimbang, membuat skor tertimbang, menentukan customer satisfaction index. Nilai CSI diatas $50 \%$ berarti pengguna jasa sudah merasa puas dengan pelayanan yang telah diberikan, dan apabila dibawah 50\% maka pengguna jasa tersebut dikatakan bahwa belum puas. Rekomendasi nilai CSI ini diklasifikasikan menjadi lima kriteria dari interpretasi nilai CSI tidak puas dengan angka indeks 0,00-0,34 sampai dengan sangat puas dengan angka indeks 0,81-1,00. Hasil Rekomendasi (CSI) dan nilai indeks kepuasan (CSI) terdapat pada Tabel 4 dan Tabel 5 berikut.

Tabel 4 Rekomendasi (CSI)

\begin{tabular}{|c|c|}
\hline Angka indeks & Interpretasi Nilai CSI \\
\hline $0,81-1,00$ & Sangat puas \\
$0,66-0,80$ & Puas \\
$0,51-0,65$ & Cukup puas \\
$0,36-0,50$ & Kurang puas \\
$0,00-0,34$ & Tidak puas \\
\hline
\end{tabular}

Tabel 5 Nilai Indeks Kepuasan (CSI)

\begin{tabular}{|c|c|c|c|c|}
\hline Atribut & $\begin{array}{c}\text { Rata- } \\
\text { rata } \\
\text { kenyata } \\
\text { an } \bar{X}\end{array}$ & $\begin{array}{c}\text { Rata- } \\
\text { rata } \\
\text { harapa } \\
\mathrm{n} \bar{Y}\end{array}$ & $\begin{array}{c}\text { Weighted } \\
\text { factor } \\
\text { (wf) } \%\end{array}$ & $\begin{array}{c}\text { Weighting } \\
\text { score (ws) }\end{array}$ \\
\hline P1 & 3,28 & 4,35 & 8,3 & 0,27 \\
P2 & 3,11 & 4,33 & 8,2 & 0,26 \\
P3 & 3,07 & 4,29 & 8,2 & 0,25 \\
P4 & 3,01 & 4,36 & 8,3 & 0,25 \\
P5 & 3,12 & 4,32 & 8,2 & 0,26 \\
P6 & 3,18 & 4,38 & 8,3 & 0,27 \\
P7 & 3,04 & 4,42 & 8,4 & 0,26 \\
P8 & 2,90 & 4,41 & 8,4 & 0,24 \\
P9 & 2,99 & 4,41 & 8,4 & 0,25 \\
P10 & 3,07 & 4,43 & 8,4 & 0,27 \\
P11 & 3,20 & 4,42 & 8,4 & 0,27 \\
P12 & 3,14 & 4,44 & 8,5 & 0,27 \\
\hline Total & 37,11 & 52,56 & 100 & 3,09 \\
\hline Customer Satisfaction Index(CSI) & 0,62 \\
\hline \multicolumn{5}{|c}{} \\
\hline
\end{tabular}

Hasil perhitungan pada Tabel 4 dan Tabel 5 menunjukan nilai CSI sebesar 0,62 yang termasuk dalam rentang interval 0,51-0,65 dan masuk dalam kategori penumpang cukup puas terhadap kinerja angkutan umum yang ada di stasiun Madiun. Namun kinerja yang cukup baik ini mebutuhkan beberapa perbaikan agar menjadi lebih baik lagi sehingga dapat menarik penumpang lebih banyak lagi untuk menggunakan angkutan umum.

\section{KESIMPULAN}

Hasil analisa terlihat bahwa tingkat kepuasan dan harapan penumpang terhadap pelayanan stasiun Madiun 
sebesar 0,62 yang termasuk dalam rentang interval 0,51 0,65 dan masuk dalam kategori penumpang cukup puas terhadap kinerja angkutan umum yang ada di stasiun Madiun. Namun kinerja angkutan umum yang cukup puas ini masih membutuhkan beberapa perbaikan diaantaranya:

1) Atribut 7 yaitu informasi lokasi dan petunjuk arah angkutan lanjutan yang mudah terlihat dan jelas terbaca oleh penumpang

2) Atribut 8 yaitu jam operasional angkutan umum

3) Atribut 9 yaitu tersedia informasi jadwal, rute angkutan umum lanjutan

4) Atribut 10 yaitu kondisi angkutan umum baik, bersih, terawat

Perlu dilakukan peremajaan armada angkutan umum yang beroperasi karena saat ini kondisi armada yang ada banyak yang sudah lama, untuk menarik minat penumpang agar mau naik angkutan umum maka perlu melakukan peremajaan demi kenyamanan penumpang. selain itu penyediaan papan informasi mengenai trayek rute yang akan dilewati angkutan umum tersebut sangat diperlukan. Jam operasional angkutan yang jelas, dan penyediaan halte serta penambahan fasilitas seperti AC sangat diperlukan untuk menarik minat penumpang di stasiun Madiun agar mau naik angkutan umum lagi.

\section{DAFTAR RUJUKAN}

J. Martilla., J. J. (1977), Importance-Performaance Analysis, Journal of Marketing.

Leliana, Arinda., Widyastuti, Hera. (2018), Analisis Kepuasan Penumpang Terhadap Kinerja Pelayanan Di Stasiun Madiun, Teknologi Penerbangan. ISSN : 2548-8090 e-ISSN : 2548-8104. 2(2), 43-48.

Lodhita, H. E. (2014), Analisis Pengaruh Kualitas Pelayan Terhadap Kepuasan Konsumen Menggunakan Metode IPA Dan CSI Studi Kasus Pada Toko Oen Malang, In Universitas Brawijaya.

Nurhidayat, D. (2017), Analysis Of Modal Transportation Performance And Satisfaction Level Of Krd Jenggala (Sidoarjo-Mojokerto). International Symposium on Transportation Studies in Developing Countries Hasanuddin University.

Putri, Maharani Ajeng., Widyastuti, Hera. (2016), Evaluasi Kinerja Dan Tingkat Kepuasan Pengguna Moda Transportasi Kereta Api Rapih Dhoho (BlitarSurabaya), In Tugas Akhir Jurusan Teknik Sipil, Institut Teknologi Sepuluh Nopember, Surabaya.

Soimun, Ahmad., Widyastuti, H. (2017), Analisis Kinerja Dan Kepuasan Kereta Api Commuter Surabaya Porong (Ind), In Tugas Akhir Jurusan Teknik Sipil, Institut Teknologi Sepuluh Nopember, Surabaya.

Sugiyono. (2017), Metode Penelitian Kuantitatif, Kualitatif, dan R\&D, Penerbit Alfabeta, Bandung.

Sulistiyani, M. W., Widyastuti, H. (2014), Evaluasi Kinerja Stasiun Pasar Turi Surabaya, Jurnal Teknik Pomits, 1(1), 1-4. 
Jurnal Rekayasa Tenik Sipil Universitas Madura Vol.5 No.1 Juni 2020 ISSN 2527-5542

Halaman Ini Sengaja Dikosongkan 


\title{
PENGARUH BAHAN TAMBAH SERBUK BAN BEKAS PADA KONSTRUKSI HOTROLLED SHEET-WEARING COURSE
}

\author{
Blima Oktaviastuti ${ }^{1}$, Arinda Leliana $^{2}$, dan Luthfil Abid $^{3}$ \\ ${ }^{I}$ Program Studi Teknik Sipil, Fakultas Teknik, Universitas Tribhuwana Tunggadewi, Malang \\ ${ }^{2}$ Program Studi Manajemen Teknologi Perkeretaapian, Politeknik Perkeretaapian Indonesia, Madiun \\ ${ }^{3}$ Jurusan Teknik Sipil, Fakultas Teknik, Universitas Negeri Malang, Malang
}

E-mail: blima.oktavia90@gmail.com,arindaleliana21@gmail.com,luthfilabid37@gmail.com

\begin{abstract}
ABSTRAK: Penelitian ini bertujuan mengetahui pemanfaatan serbuk ban bekas sebagai bahan tambahan pada konstruksi jalan. Benda uji Kadar Aspal Optimum (KAO) masing-masing dibuat 3 buah dengan kadar aspal 4\%, 4,5\%, $5 \%, 5,5 \%, 6 \%$, dan 6,5\%. Benda uji dengan tambahan serbuk ban bekas masing-masing dibuat 3 buah dengan kadar serbuk ban karet bekas $0 \%, 1,5 \%, 3 \%, 4,5 \%$, dan $6 \%$. Hasil penelitian ini menunjukkan bahwa KAO sebesar 6,03\%. Kemudian untuk Parameter Marshall (PM) berdasarkan penambahan limbah serbuk ban bekas diperoleh hasil: (1) nilai PM 0\% untuk nilai stabilitas $2224 \mathrm{~kg}$, nilai flow 3,98 mm, nilai MQ $552 \mathrm{~kg} / \mathrm{mm}$, nilai VIM 4,01\%, VMA 19,70\% dan VFA 79,67\%; (2) nilai PM 1,5\% untuk nilai stabilitas $2296 \mathrm{~kg}$, nilai flow 4,53 mm, nilai MQ $509 \mathrm{~kg} / \mathrm{mm}$, nilai VIM 3,82\%, nilai VMA 19,63\% dan nilai VFA 80,54\%; (3) nilai PM 3\% untuk nilai stabilitas $1674 \mathrm{~kg}$, nilai flow 4,57 mm, nilai MQ $367 \mathrm{~kg} / \mathrm{mm}$, nilai VIM 2,78\%, VMA 19,20\%, dan nilai VFA 85,50\%; (4) nilai PM 4,5\% untuk nilai stabilitas $1055 \mathrm{~kg}$, nilai flow 4,45 mm, nilai MQ $247 \mathrm{~kg} / \mathrm{mm}$, nilai VIM 2,42\%, nilai VMA 19,04\% dan nilai VFA 87,30\%; (5) nilai PM 6\% untuk nilai stabilitas $1075 \mathrm{~kg}$, nilai flow 4,60 mm, nilai MQ $228 \mathrm{~kg} / \mathrm{mm}$, nilai VIM 1,95\%, nilai VMA $18,85 \%$, dan nilai VFA $89,63 \%$.
\end{abstract}

Kata Kunci: Serbuk Ban Bekas, Bahan Tambahan, HRS-WC

\section{PENDAHULUAN}

Kebutuhan sarana dan prasarana transportasi sangat diperlukan oleh negara maju seperti Indonesia. Transportasi memiliki peran penting dalam mensukseskan pembangunan. Pembangunan dan pemeliharaan jalan harus diperhatikan agar hubungan antar daerah tidak terputus. Oleh sebab itu, peran dari penunjang kebutuhan transportasi memegang peranan penting.

Kondisi tersebut belum berlaku di Indonesia dengan presentase terbesar kerusakan jalan diakibatkan oleh konstruksi jalan yang tidak memenuhi standar dan adanya pengendalian air yang buruk. Kencana (https://www.liputan6.com, diakses 23 April 2020) bahwa menurut Himpunan Pengembang Jalan Indonesia (HPJI) terdapat tiga faktor penyebab kerusakan jalan di Indonesia, meliputi: (1) proses desain; (2) proses pelaksanaan; dan (3) proses pemanfaatan

Perkembangan transportasi darat di Indonesia yang semakin maju menghasilkan banyak limbah kendaraan bermotor, salah satunya adalah limbah ban bekas. Serbuk ban bekas diperoleh dari vulkanisir ban karet memiliki potensi yang dapat dimanfaatkan dalam campuran aspal beton. Hasil campuran tersebut bermanfaat untuk meningkatkan stabilitas dan durabilitasnya. Pada proses perencanaan perkerasan jalan, material yang digunakan meliputi agregat, aspal, dan filler sebagai bahan pengisi campuran aspal beton.

Bukit, N. dan Frida, E. (2011:124) bahwa terdapat sekitar enam ribu ton ban bekas dihasilkan setiap tahun di Eropa, Amerika, dan Jepang yang akan terus meningkat sejalan dengan meningkatnya industri otomotif dunia. Upaya pemusnahan dengan cara pembakaran yang biasa dilakukan dapat menimbulkan dampak polusi yang berbahaya, karena berpengaruh buruk pada kesehatan manusia. Perlu adanya suatu usaha yang serius untuk menangani dan mengolah limbah ban bekas tersebut agar tidak menimbulkan masalah terhadap lingkungan.

Serbuk ban bekas yang digunakan dalam campuran aspal beton berupa hasil parutan ban kendaraan yang biasa dikenal sebagai scrap tire rubber. Serbuk ban bekas merupakan limbah dari vulkanisir ban sehingga harganya lebih murah. Mashuri dan Batti (2011:206) menyimpulkan bahwa kandungan kimia serbuk ban bekas berdasarkan hasil pengujian laboratorium kimia ITB Bandung meliputi: Karbon (32,19\%); Silikat (1,6\%); Sulfur (2,13\%); Karet (64,04\%). Hasib (2008) dalam penelitiannya, mendapatkan hasil bahwa kadar aspal optimum dengan penambahan ban karet 1\%, 2\%, 3\%, 4\%, $5 \%$, dan $6 \%$, diperoleh hasil stabilitas, Flow, VIM, VMA yang lebih tinggi, sedangkan nilai Marshall Quotient lebih kecil dibandingkan dengan nilai pada kadar aspal optimum tanpa penambahan kadar dan ban karet. Leksminingsih (2005) dalam penelitiannya bahwa perencanaan campuran aspal yang menggunakan bahan tambah katalis bekas $0 \%, 5 \%, 7,5 \%$ dan $10 \%$ dengan spesifikasi AC-WC, pada penambahan 5\% katalis menghasilkan stabilitas Marshall sebesar 1350kg, lebih tinggi 22,2\% terhadap campuran standar tanpa bahan tambah. Campuran standar mempunyai stabilitas Marshall $1050 \mathrm{~kg}$ dan stabilitas dinamis 2864 lintasan/mm. Penelitian tersebut digunakan sebagai acuan komposisi campuran serbuk ban bekas dengan kapur. Perencanaan campuran aspal dengan penambahan serbuk ban bekas dapat menggunakan $2 \%, 4 \%, 6 \%, 8 \%$ dan $10 \%$.

Berdasarkan uraian tersebut, tulisan ini bertujuan: (1) mengetahui kadar aspal optimum yang dibutuhkan untuk menentukan benda uji, dan (2) mengetahui parameter Marshall yang ditinjau dari penambahan limbah ban bekas sebesar $0 \% ; 1,5 \% ; 3 \% ; 4,5 \%$; dan $6 \%$. 


\section{METODE PENELITIAN}

Penelitian ini menggunakan metode kuantitatif dan rancangan penelitian eksperimen.

\section{1) Bahan Penelitian}

Material yang dipergunakan dalam penelitian ini meliputi:

- Aspal keras penetrasi 60/70

- Agregat

- Serbuk ban bekas tertahan di saringan No.30 lolos saringan No. 12

- Bahan pengisi (filler)

- Bahan-bahan lain yang menunjang penelitian seperti: gas elpiji, minyak tanah, solar, bensin dan oli.

2) Alat

Peralatan utama yang digunakan adalah alat uji tekan Marshall yang terdiri dari :

1) Kepala penekan berbentuk lengkung.

2) Cincin penguji/proving ring berkapasitas $22,2 \mathrm{KN}$ (5000 lbf dan 10000 lbf) yang dilengkapi dengan arloji tekan dengan ketelitian $0,0025 \mathrm{~cm}(0,001$ inch).

3) Arloji penunjuk nilai kelelehan.

\section{PELAKSANAAN PENELITIAN}

Secara garis besar penelitian ini memiliki 3 tahapan dalam pelaksanaannya. Tahapan tersebut meliputi:

1) Tahap Persiapan Penelitian

- Mencari rujukan-rujukan dari buku, surat kabar, majalah, internet dan sumber lainnya yang masih berhubungan dengan penelitian

- Menyiapkan bahan penelitian yang memenuhi syarat

- Menyiapkan peralatan laboratorium

\section{2) Tahap Pelaksanaan Penelitian}

- Memeriksa bahan penelitian dengan cara laboratorium yang terdiri dari agregat dan aspal keras 60/70

- Menyiapkan dan membuat benda uji kontrol campuran agregat ditambah aspal

- Melakukan pengujian dengan alat Marshall

- Membuat benda uji kontrol (tanpa campuran serbuk ban bekas)

- Membuat benda uji penelitian campuran aspal + agregat + serbuk ban bekas. Kadar serbuk ban bekas adalah $0 \%, 1,5 \%, 3 \%, 4,5 \%$, dan $6 \%$

- Melakukan pengetesan dengan alat Marshall

\section{3) Tahap Penyelesaian Penelitian}

- Melakukan analisis data

- Membuat draft laporan

\section{HASIL}

\section{1) Pengujian Agregat}

Hasil pengujian agregat kasar dan agregat halus dengan persyaratan sesuai dengan spesifikasi Pelaksanaan Lapis Campuran Beraspal Panas Revisi SNI 03-17371989, dapat dilihat pada Tabel 1 di bawah ini:

2) Pengujian Aspal

Hasil pengujian aspal keras penetrasi 60/70 sesuai dengan spesifikasi Pelaksanaan Lapis Campuran Beraspal
Panas Revisi SNI 03-1737-1989, dapat dilihat pada Tabel 2 berikut:

Tabel 1. Hasil Pengujian Agregat

\begin{tabular}{|c|l|c|c|}
\hline No. & Pengujian & Hasil & Spesifikasi \\
\hline & Agregat Kasar & & \\
\hline 1. & Berat Jenis $\left(\mathrm{gr} / \mathrm{cm}^{3}\right)$ & 3,08 & Min. 2,5 \\
\hline 2. & Penyerapan $(\%)$ & 2,29 & Max. 3 \\
\hline 3. & Keausan $(\%)$ & 35,22 & Max. 40 \\
\hline & Agregat Halus & & \\
\hline 1. & Berat Jenis $\left(\mathrm{gr} / \mathrm{cm}^{3}\right)$ & 2,62 & Min. 2,5 \\
\hline 2. & Penyerapan $(\%)$ & 1,12 & Max. 3 \\
\hline
\end{tabular}

Tabel 2. Hasil Pengujian Aspal Keras Penetrasi 60/70

\begin{tabular}{|c|l|c|c|c|}
\hline \multirow{2}{*}{ No. } & \multicolumn{1}{|c|}{ Pengujian } & \multirow{2}{*}{$\begin{array}{c}\text { Hasil } \\
\text { Pengujian }\end{array}$} & \multicolumn{2}{c|}{ Spesifikasi } \\
\cline { 4 - 5 } & & Min & Maks \\
\hline 1. & Berat Jenis $\left(\mathrm{gr} / \mathrm{cm}^{3}\right)$ & 1,03 & 1 & - \\
\hline 2. & Penetrasi $(\mathrm{mm})$ & 64 & 60 & 79 \\
\hline 3. & $\begin{array}{l}\text { Penetrasi Setelah } \\
\text { Kehilangan Berat } \\
(\mathrm{mm})\end{array}$ & 65,6 & 54 & - \\
\hline 4. & Titik Lembek $\left({ }^{\circ} \mathrm{C}\right)$ & 54,45 & 48 & 58 \\
\hline 5. & $\begin{array}{l}\text { Titik Lembek } \\
\text { Setelah Kehilangan } \\
\text { Berat }\left({ }^{\circ} \mathrm{C}\right)\end{array}$ & 53,6 & 48 & 58 \\
\hline 6. & Titik Nyala $\left({ }^{\circ} \mathrm{C}\right)$ & 326,5 & 200 & - \\
\hline 7. & Daktilitas $(\mathrm{cm})$ & 140 & 100 & - \\
\hline 8. & $\begin{array}{l}\text { Daktilitas Setelah } \\
\text { Kehilangan Berat } \\
(\mathrm{cm})\end{array}$ & 62,86 & 50 & - \\
\hline 9. & $\begin{array}{l}\text { Kehilangan Berat } \\
\text { Aspal }(\%)\end{array}$ & 0,38 & - & 0,8 \\
\hline
\end{tabular}

\section{3) Penentuan Kadar Aspal Optimum}

Kadar aspal optimum diperoleh dengan mengambil beberapa indikator Marshall antara lain Stabilitas, Flow, Marshall Quotient, VIM, dan VMA yang memenuhi syarat dan diambil nilai yang paling ideal. Tabel 3 merupakan hasil pengujian yang telah dilakukan, yang memperoleh nilai kadar aspal optimum sebesar $6,03 \%$.

\section{4) Pengujian Marshall Benda Uji Kontrol}

Hasil pengujian dari parameter Marshall benda uji kontrol dapat dilihat pada Tabel 4 berikut:

Tabel 4. Hasil Pengujian Marshall Benda Uji Kontrol

\begin{tabular}{|l|l|c|c|c|}
\hline \multirow{2}{*}{ No. } & \multicolumn{1}{|c|}{$\begin{array}{c}\text { Data } \\
\text { Marshall }\end{array}$} & $\begin{array}{c}\text { Hasil } \\
\text { Pengujian }\end{array}$ & \multicolumn{2}{|c|}{ Spesifikasi } \\
\cline { 4 - 5 } & Stabilitas (kg) & $2379-2694$ & 800 & Maks. \\
\hline 2. & Flow (mm) & $1,34-3,87$ & 3,0 & - \\
\hline 3. & $\begin{array}{l}\text { Marshall } \\
\text { Quotient } \\
\text { (kg/mm) }\end{array}$ & $1953-687$ & 250 & - \\
\hline 4. & VIM (\%) & $19,68-3,27$ & 3 & 6 \\
\hline 5. & VMA (\%) & $21,97-20,48$ & 18 & - \\
\hline 6. & VFA (\%) & $10,43-84,01$ & 68 & - \\
\hline 7. & $\begin{array}{l}\text { Kadar Aspal } \\
\text { Optimum }(\%)\end{array}$ & 6,03 & \multicolumn{2}{l}{} \\
\hline
\end{tabular}


Tabel 3. Penentuan Kadar Aspal Optimum

\begin{tabular}{|c|c|c|c|c|c|c|c|c|c|}
\hline \multicolumn{10}{|c|}{ Penentuan Kadar Aspal Optimum } \\
\hline \multirow{2}{*}{$\begin{array}{c}\text { Parameter } \\
\text { Marshall }\end{array}$} & \multirow{2}{*}{ Satuan } & \multicolumn{2}{c|}{ \% Kadar Serbuk Ban Terhadap Berat Campuran } & \multicolumn{2}{|c|}{ Spesifikasi } \\
\cline { 2 - 11 } & & $\mathbf{4}$ & $\mathbf{4 , 5}$ & $\mathbf{5}$ & $\mathbf{5 , 5}$ & $\mathbf{6}$ & $\mathbf{6 , 5}$ & Min. & Max. \\
\hline Stabilitas & $\mathrm{kg}$ & 2379 & 2383 & 2425 & 2417 & 2436 & 2694 & 800 & - \\
\hline Flow & $\mathrm{mm}$ & 1,34 & 1,53 & 2,87 & 3,54 & 3,68 & 3,87 & 3 & - \\
\hline $\begin{array}{c}\text { Marshall } \\
\text { Quotient }\end{array}$ & $\mathrm{kg} / \mathrm{mm}$ & 1953 & 1590 & 846 & 680 & 663 & 697 & 250 & - \\
\hline VIM & $\%$ & 19,68 & 15,75 & 10,96 & 6,97 & 3,56 & 3,27 & 3 & 6 \\
\hline VMA & $\%$ & 21,97 & 21,31 & 20,32 & 19,75 & 19,46 & 20,48 & 18 & - \\
\hline VFA & $\%$ & 10,43 & 26,10 & 46,06 & 64,96 & 81,71 & 84,01 & 68 & - \\
\hline
\end{tabular}

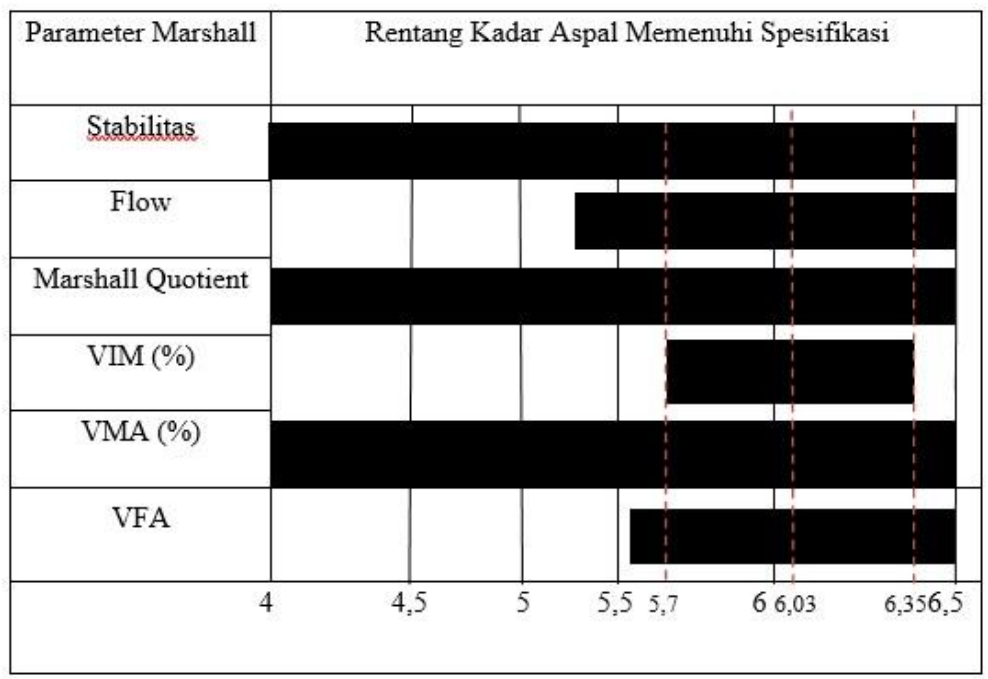

Gambar 1. Kadar Aspal Optimum

5) Hasil Pengujian Marshall Benda Uji Penelitian

Tambahan Serbuk Ban Bekas 0\%, 1,5\%, 3\%, $4,5 \%$, dan $6 \%$

Hasil pengujian dari parameter Marshall benda uji penelitian dengan tambahan serbuk ban bekas $0 \%, 1,5 \%$, $3 \%, 4,5 \%$, dan $6 \%$ diperoleh hasil sesuai pada Tabel 5 di bawah ini:

Tabel 5. Hasil Pengujian Marshall Benda Uji Penelitian

\begin{tabular}{|c|l|c|c|c|}
\hline \multirow{2}{*}{ No. } & \multirow{2}{*}{$\begin{array}{c}\text { Data } \\
\text { Marshall }\end{array}$} & \multirow{2}{*}{$\begin{array}{c}\text { Hasil } \\
\text { Pengujian }\end{array}$} & \multicolumn{2}{c|}{ Spesifikasi } \\
\cline { 4 - 5 } & Min. & Maks. \\
\hline 1. & Stabilitas (kg) & $2224-1075$ & 800 & - \\
\hline 2. & Flow (mm) & $3,98-4,60$ & 3,0 & - \\
\hline 3. & $\begin{array}{l}\text { Marshall } \\
\text { Quotient } \\
\text { (kg/mm) }\end{array}$ & $552-228$ & 250 & - \\
\hline 4. & VIM (\%) & $4,01-1,95$ & 3 & 6 \\
\hline 5. & VMA (\%) & $19,70-18,85$ & 18 & - \\
\hline 6. & VFA (\%) & $79,67-89,63$ & 68 & - \\
\hline
\end{tabular}

\section{PEMBAHASAN}

1) Penambahan Serbuk Ban Bekas Berdasarkan Parameter Marshall Stabilitas

Sukirman (2007) pengujian nilai stabilitas adalah kemampuan maksimum beton aspal padat menerima beban sampai terjadi kelelehan plastis. Berdasarkan Tabel
5 saat campuran $0 \%$ nilai stabilitas $2224 \mathrm{~kg}$, kemudian mengalami kenaikan pada kadar serbuk ban $1,5 \%$ sebesar $2296 \mathrm{~kg}$, selanjutnya pada kadar serbuk ban $3 \%$ mengalami penurunan stabilitas menjadi $1674 \mathrm{~kg}$, kadar serbuk ban 4,5\% nilai stabilitas $1055 \mathrm{~kg}$, dan kadar serbuk ban $6 \%$ nilai stabilitas menjadi $1075 \mathrm{~kg}$. Hal ini disebabkan karena serbuk ban terlalu banyak sehingga menyebabkan film aspal bertambah tipis yang mempengaruhi daya ikat aspal dan penguncian antar agregat semakin berkurang. Kadar penambahan serbuk ban telah memenuhi spesifikasi Pelaksanaan Lapis Campuran Beraspal Panas Revisi SNI 03-1737-1989, stabilitas minimal $800 \mathrm{~kg}$.

Hal ini diperkuat penelitian Faisal, dkk (2014) bahwa penggunaan parutan ban dalam bekas kendaraan roda empat dapat membantu meningkatkan nilai stabilitas.

\section{2) Flow}

Sukirman (2007) flow adalah besarnya perubahan plastis dari beton aspal padat akibat adanya beban sampai batas keruntuhan. Berdasarkan Tabel 5, semakin banyak kadar serbuk ban, nilai flow menunjukkan peningkatan mulai dari $0 \%$ sampai 3\%. Kadar serbuk ban $0 \%$ nilai flow 3,98mm, kadar serbuk ban $1,5 \%$ nilai flow $4,53 \mathrm{~mm}$, kadar serbuk ban $3 \%$ nilai flow $4,57 \mathrm{~mm}$, kemudian pada kadar serbuk ban $4,5 \%$ nilai flow mengalami penurunan yaitu $4,45 \mathrm{~mm}$, selanjutnya kadar serbuk ban $6 \%$ nilai flow 
meningkat kembali menjadi 4,60 mm. Nilai flow tertinggi dengan tambahan serbuk ban bekas adalah 4,60mm, sedangkan nilai flow terrendah tanpa tambahan serbuk ban bekas adalah $3,87 \mathrm{~mm}$. Hasil tersebut menunjukkan bahwa kadar penambahan serbuk ban memenuhi spesifikasi Pelaksanaan Lapis Campuran Beraspal Panas Revisi SNI 03-1737-1989, dengan nilai flow minimal $3 \mathrm{~mm}$.

Faisal, dkk (2014) tambahan parutan ban dalam bekas kendaraan roda empat untuk nilai flow aspal beton AC$\mathrm{BC}$ menunjukkan peningkatan dari penggunaan $0 \%$ sebesar $3,6 \mathrm{~mm}$, parutan ban dalam bekas $1 \%$ naik menjadi 4,3mm, kemudian terus menurun secara signifikan mulai dari $2 \%$ dengan nilai flow 4,1 sampai $5 \%$ dengan nilai flow $3,3 \mathrm{~mm}$.

\section{3) MQ (Marshall Quotient)}

Marshall Quotient adalah perbandingan antara nilai stabilitas dengan nilai flow (Sukirman, 2007). Nilai MQ pada Tabel 5 dapat dilihat bahwa semakin banyak penambahan serbuk ban yang digunakan, maka nilai MQ cenderung semakin menurun dan nilai MQ terendah yaitu pada kadar serbuk ban $6 \%$ sebesar $228 \mathrm{~kg} / \mathrm{mm}$. Kadar serbuk ban $4,5 \%$ dan $6 \%$ tidak memenuhi spesifikasi yang ditentukan Pelaksanaan Lapis Campuran Beraspal Panas Revisi SNI 03-1737-1989, dengan syarat MQ minimal $250 \mathrm{~kg} / \mathrm{mm}$.

Faisal, dkk (2014) nilai MQ campuran aspal beton AC-BC dengan variasi parutan ban dalam bekas kendaraan roda empat turun dari $0 \%$ sampai $1 \%$, kemudian meningkat kembali pada $1 \%$ hingga $5 \%$. Nilai MQ tertinggi diperoleh pada $5 \%$ yaitu $734,96 \mathrm{~kg} / \mathrm{mm}$ dan terendah pada $1 \%$ yaitu $479,77 \mathrm{~kg} / \mathrm{mm}$, kemudian meningkat kembali hingga $5 \%$ parutan ban dalam bekas kenderaan roda 4. Nilai MQ campuran aspal beton AC$\mathrm{BC}$ dari semua variasi parutan ban dalam bekas kendaraan roda 4 masih memenuhi persyaratan untuk nilai MQ yaitu $>250 \mathrm{~kg} / \mathrm{mm}$.

\section{4) VIM (Void In Mix)}

Lengkung VMA yang akan turun sampai mencapai nilai minimum dan kemudian kembali bertambah dengan bertambahnya kadar aspal (Sukirman, 2007). Nilai VIM pada Tabel 5 bahwa semakin banyak penambahan serbuk ban yang digunakan, maka akan berpengaruh terhadap penurunan nilai VIM, dan yang terendah pada kadar serbuk ban $6 \%$ dengan nilai VIM 1,95\%. Dari semua kadar penambahan, kadar serbuk ban 3\%, 4,5\% dan $6 \%$ tidak memenuhi spesifikasi yang ditentukan Pelaksanaan Lapis Campuran Beraspal Panas Revisi SNI 03-17371989, sebab syarat nilai VIM maksimal $6 \%$ dan minimal $3 \%$.

Faisal, dkk (2014) nilai VIM campuran aspal beton AC-BC dengan variasi parutan ban dalam bekas kenderaan roda empat terjadi penurunan nilai VIM pada setiap penambahan kadar serbuk ban.

\section{5) VMA ( Void In Mineral Agregat)}

VMA yaitu volume rongga yang terdapat diantara butir agregat dari suatu campuran aspal yang telah dipadatkan (Sukirman, 2007). Nilai VMA cenderung mengalami penurunan pada setiap penambahan serbuk ban. Hal ini diperkuat dengan rangkuman data pada Tabel 4.5 nilai VMA terendah yaitu kadar serbuk ban $6 \%$ nilai VMA $18,85 \%$. Semakin bertambah kadar serbuk ban, maka jumlah rongga dalam campuran akan berkurang. Semua rentang kadar tambahan serbuk ban bekas telah memenuhi spesifikasi Pelaksanaan Lapis Campuran Beraspal Panas Revisi SNI 03-1737-1989, dengan syarat VMA minimal $18 \%$.

Gosali, G., dkk. (2016) menyimpulkan dalam penelitiannya bahwa terjadi penurunan nilai VMA pada semua campuran serbuk ban bekas yaitu kadar $1 \%, 2 \%$, dan $3 \%$. Hasil penambahan serbuk ban karet yang memiliki nilai lebih rendah (dibandingkan dengan campuran tanpa karet) hasilnya masih diatas batas spesifikasi minimum, sehingga masih dapat digunakan sebagai campuran lapisan perkerasan.

\section{6) VFA (Void Filled with Asphalt) Penambahan Serbuk Ban Bekas}

VFA merupakan banyaknya pori antara butir agregat didalam beton aspal padat yang terisi oleh aspal (Sukirman, 2007). Nilai VFA pada Tabel 5 menunjukkan bahwa semakin banyak tambahan serbuk ban yang digunakan dalam campuran, maka nilai VFA semakin naik dan nilai VFA tertinggi yaitu pada kadar serbuk ban $6 \%$ dengan nilai VFA 89,63\%. Peningkatan nilai VFA disebabkan dengan penambahan kadar serbuk ban yang dapat mengurangi jumlah rongga dalam campuran. Sehingga, mengakibatkan nilai VFA cenderung mengalami suatu peningkatan. Semua rentang kadar penambahan serbuk ban bekas telah memenuhi spesifikasi Pelaksanaan Lapis Campuran Beraspal Panas Revisi SNI 03-1737-1989, dengan syarat VFA minimal 68\%.

Penelitian Faisal, dkk (2014) nilai VFA terjadi peningkatan seiring dengan bertambahnya persentase parutan ban dalam bekas kendaraan roda empat, walaupun peningkatan nilai VFA tidak terlalu besar. Meningkatnya nilai VFA disebabkan bertambahnya persentase parutan ban dalam bekas kendaraan roda empat dalam campuran aspal beton AC-BC. Hal ini mengakibatkan aspal dan parutan ban dalam bekas kendaraan roda empat banyak mengisi pori-pori atau rongga campuran serta semakin tebalnya selimut material. Nilai VFA masih memenuhi persyaratan untuk campuran aspal beton AC-BC yaitu lebih besar dari $63 \%$.

\section{KESIMPULAN}

1) Penentuan nilai KAO pada campuran HRS-WC berdasarkan parameter Marshall

Penentuan nilai Kadar Aspal Optimum (KAO) sebesar $6,03 \%$ berdasarkan semua hasil stabilitas, kelelehan (flow), Marshall Quotient (MQ), rongga terisi aspal (VFA), rongga dalam campuran (VIM), dan rongga dalam agregat (VMA).

2) Penambahan limbah serbuk ban bekas berdasarkan parameter Marshall

1) Penambahanlimbah serbuk ban bekas $0 \%$ Pada kadar penambahan serbuk ban bekas $0 \%$ nilai stabilitas $2224 \mathrm{~kg}$, flow menunjukkan nilai $3,98 \mathrm{~mm}$, nilai MQ (Marshall Quotient) $552 \mathrm{~kg} / \mathrm{mm}$, nilai VIM (Void in Mixture) 4,01\%, VMA (Void in Mineral 
Agregate) 19,70\%, sedangkan VFA (Void Filled with Asphalt) $79,67 \%$.

2) Penambahan limbah serbuk ban bekas $1,5 \%$

Pada kadar penambahan serbuk ban bekas $1,5 \%$ nilai stabilitas $2296 \mathrm{~kg}$, nilai flow 4,53mm, nilai MQ (Marshall Quotient) 509kg/mm, nilai VIM (Void in Mixture) 3,82\%, VMA (Void in Mineral Agregate) 19,63\%, sedangkan VFA (Void Filled with Asphalt) $80,54 \%$.

3) Penambahan limbah serbuk ban bekas $3 \%$

Pada kadar penambahan serbuk ban bekas 3\% nilai stabilitas $1674 \mathrm{~kg}$, nilai flow $4,57 \mathrm{~mm}$, nilai MQ (Marshall Quotient) 367kg/mm, nilai VIM (Void in Mixture) 2,78\%, VMA (Void in Mineral Agregate) 19,20\%, sedangkan VFA (Void Filled with Asphalt) $85,50 \%$.

4) Penambahan limbah serbuk ban bekas $4,5 \%$

Pada kadar penambahan serbuk ban bekas $4,5 \%$ nilai stabilitas $1055 \mathrm{~kg}$, nilai flow $4,45 \mathrm{~mm}$, nilai MQ (Marshall Quotient) 247kg/mm, nilai VIM (Void in Mixture) 2,42\%, VMA (Void in Mineral Agregate) 19,04\%, sedangkan VFA (Void Filled with Asphalt) $87,30 \%$.

5) Penambahan limbah serbuk ban bekas $6 \%$

Pada kadar penambahan serbuk ban bekas $6 \%$ nilai stabilitas $1075 \mathrm{~kg}$, nilai flow 4,60mm, nilai MQ (Marshall Quotient) 228kg/mm, nilai VIM (Void in Mixture) 1,95\%, VMA (Void in Mineral Agregate) 18,85\%, sedangkan VFA (Void Filled with Asphalt) $89,63 \%$.

\section{DAFTAR PUSTAKA}

Departemen Pekerjaan Umum Tahun 1989. Pelaksanaan Lapis Campuran Beraspal Panas Revisi SNI No.03 1737-1989. Jakarta: Yayasan Badan Penerbit Pekerjaan Umum Jakarta. (Online), http://www.pdfoz.net/k-14431257.html, diakses 23 April 2020.

Faisal, Sofyan, M.Shaleh, M. I. (2014). Karakteristik Marshall Campuran Aspal Beton Ac-Bc Menggunakan Material Agregat. Jurnal Teknik Sipil, Pascasarjana Universitas Syiah Kuala, ISSN 23020253, 3(3), 38-48.

Gosali, G., Jaya, H., Wulandari, P. S., \& Patmadjaja, H. (2016). Pengaruh Penambahan Serbuk Ban Karet Mesh \#80 Pada Campuran Laston Untuk Perkerasan Jalan Raya. Jurnal Dimensii Pratama Teknik Sipil, 5(1), 1-8.

Hasib. 2008. Pengaruh Penambahan Ban Karet pada Laston Ditinjau Terhadap Parameter Marshall. Skripsi. Tidak diterbitkan. Malang: Universitas Negeri Malang.

Kencana, Maulandy R.B. 2018. Usul HPJI agar Fasilitas Jalan Tak Cepat Rusak, (Online), https://www.liputan6.com, diakses 23 April 2020.

Leksminingsih. (2001). Pengaruh Penambahan Katalis Bekas (SPENT CATALYST) terhadap Kinerja Beraspal. In Skripsi, (Online), http://www.lontar.ui.ac.id, diakses 23 April 2020.
Mashuri, \& Batti. (2011). Pemanfaatan Material Limbah Pada Campuran Panas. Makalah Ilmiah Teknik Sipil. (3): 204-212.

Nurdin Bukit dan Erna Frida. (2011). Pengolahan ban bekas berwawasan lingkungan menjadi bahan bamper pada outomotif. Jurnal Teknologi Indonesia, 34, 123131.

Sukirman, S. 2007. Beton Aspal Campuran Panas. Jakarta: Yayasan Obor Indonesia.

Suryadharma, H. dan Susanto, B. 1999. Rekayasa Jalan Raya. Yogyakarta: Universitas Atma Jaya. 
Jurnal Rekayasa Tenik Sipil Universitas Madura Vol.5 No.1 Juni 2020 ISSN 2527-5542

Halaman Ini Sengaja Dikosongkan 


\title{
Evaluasi Kinerja Sistem Manajemen Keselamatan dan Kesehatan Kerja (SMK3) Pada Proyek Attic Showroom dan East Coast Center 2 Di Surabaya
}

\author{
Juliandres Unitly ${ }^{1,}$ Feri Harianto ${ }^{2}$ dan Dian Listyaningsih ${ }^{3}$ \\ ${ }^{1,2}$ Jurusan Teknik Sipil, Fakultas Teknik Sipil dan Perencanaan,ITATS, Surabaya \\ E-mail: julianandrewunitly@gmail.com ${ }^{1}$,gokbio@yahoo.com ${ }^{2}$,dianlistyaningsih@itats.ac.id ${ }^{3}$
}

\begin{abstract}
ABSTRAK: Sektor konstruksi adalah salah satu sektor yang paling beresiko terhadap kecelakaan tenaga kerja, kerugian jiwa, material, uang, dan waktu merupakan akibat-akibat yang tentu saja akan menghambat secara langsung pelaksanaan proyek konstruksi. Untuk mencegah kecelakaan pada pelaksanaan pekerjaan konstruksi diwajibkan untuk menerapkan Sistem Manajemen Keselamatan Dan Kesehatan Kerja (SMK3) di lokasi kerja. Oleh karena itu penelitian ini bertujuan untuk mengetahui pelaksanaan penerapan Sistem Manajemen Keselamatan Dan Kesehatan Kerja (SMK3) dan perbedaan kinerja pada proyek konstruksi yang ada di kota surabaya. Penelitian ini menggunakan metode Fisher Exact Probability dengan pengambilan data yang dilakukan melalui kuesioner yang telah dibagikan kepada masingmasing responden sesuai kriteria yang telah ditentukan pada proyek yang diteliti. hasil dari penelitian ini berdasarkan Peraturan Mentri Tenaga Kerja (permenaker) no.5 tahun 1996, untuk Proyek Attic Showroom Dharmahusada nilai ratarata pencapaian adalah 76,74\% dengan predikat baik, dan Proyek East Coast Center 2 nilai rata-rata pencapaian 84,92\% dengan predikat memuaskan. Sedangkan perbandingan antara kedua proyek berdasarkan setiap poin pertanyaan menunjukan perbedaan yang signifikan diukur dari 12 kriteria audit Sistem Manajemen Keselamatan dan Kesehatan Kerja (SMK3) menurut permenaker no.50 tahun 1996 terdapat 8 item yang memiliki perberbedaan yang signifikan dan 4 item yaitu pada poin Pembangunan dan Pemeliharaan Komitmen, poin Pembuatan dan Pendokumentasian K3, poin keamanan bekerja berdasarkan SMK3, serta pada poin Pelaporan dan Perbaikan Kekurangan tidak terdapat perbedaan yang signifikan.
\end{abstract}

Kata Kunci : keselamatan, kesehatan, manajemen k3, perbandingan, SMK3

\section{PENDAHULUAN}

Industri konstruksi adalah industri yang paling beresiko terhadap kecelakaan tenaga kerja, Kecelakaan kerja yang terjadi pada proyek konstruksi menjadi salah satu penyebab terganggunya atau terhentinya aktivitas pekerjaan proyek. oleh karena itu, pada saat pelaksanaan pekerjaan konstruksi diwajibkan untuk menerapkan Sistem Manajemen Keselamatan dan Kesehatan Kerja (SMK3) dilokasi kerja dimana masalah keselamatan dan kesehatan kerja ini juga merupakan bagian dari perencanaan dan pengendalian proyek. Dengan demikian perusahaan akan semakin diuntungkan dalam upaya pencapaian tujuannya Untuk mencegah kecelakaan pada pelaksanaan pekerjaan (Harianto, 2015)

Permasalahan sistem manajemen keselamatan dan kesehatan kerja (SMK3) secara umum di Indonesia masih saja terabaikan, karena hal ini ditunjukkan dengan masih tingginya angka kecelakaan kerja yang terjadi pada proyek konstruksi.

Sesuai dengan data Badan Penyelenggara Jaminan Sosial (BPJS) Ketenagakerjaan, sampai akhir 2015 telah terjadi kecelakaan kerja sebanyak 105.182, untuk kasus kecelakaan berat yang mengakibatkan kematian tercatat sebanyak 2.375 kasus dari total jumlah kecelakaan kerja, dan cenderung terus meningkat sebanyak 123.000 kasus kecelakaan kerja tercatat sepanjang tahun 2017. Kondisi inilah mencerminkan kesiapan daya saing perusahaan Indonesia di dunia internasional masih sangat minim. Indonesia akan mengalami kesulitan menghadapi pasar global karena mengalami ketidakefisienan penyerapan tenaga kerja (produktivitas tenaga kerja yang rendah).

Sistem manajemen keselamatan dan kesehatan kerja merupakan aspek penting dalam usaha meningkatkan kesejahteraan serta produktivitas karyawan. Apabila tingkat keselamatan kerja sangat tinggi, maka kecelakaan yang menyebabkan sakit, cacat, dan kematian dapat ditekan sekecil mungkin. Apabila keselamatan kerja rendah, maka hal tersebut akan berpengaruh buruk terhadap kesehatan sehingga berakibat pada produktivitas yang menurun (Hariandja, 2013).

Keberhasilan penerapan keselamatan dan kesehatan kerja dalam suatu proyek dapat dilihat dari tingkat pencapaian nilai ukur menurut standar nilai yang tertulis dalam suatu peraturan pemerintah. Penelitian ini akan mengevaluasi bagaimana keberhasilan penerapan dan pelaksanaan Sistem Manajemen Keselamatan dan Kesehatan Kerja (SMK3) pada beberapa proyek pembangunan yang ada di Surabaya dilihat dari tingkat keberhasilan penerapannya. Tujuan penelitian ini adalah untuk Mengetahui Pelaksanaan Penerapan Sistem Manajemen Keselamatan dan Kesehatan Kerja (SMK3) Pada Proyek Kontruksi dan Perbedaan Kinerja Sistem Manajemen Keselamatan dan Kesehatan Kerja (SMK3) Pada Proyek Konstruksi.

\section{LANDASAN TEORI}

Pengertian keselamatan dan kesehatan kerja (K3)

Keselamatan dan kesehatan kerja (K3) adalah segala kegiatan untuk menjamin. Menghindari dan melindungi keselamatan dan kesehatan tenaga kerja melalui upadaya pencegahan kecelakaan kerja dan penyakit akibat kerja.

Keselamatan dan kesehatan kerja ialah rangkaian upaya dan usaha untuk dapat menciptakan suasana yang aman dan tentram bagi para karyawan yang bekerja pada perusahaan tersebut (Suma'mur, 2001).

\section{Keselamatan kerja}

Keselamatan kerja adalah upaya utama untuk pencegahan kecelakaan, cacat bahkan sampai pada kematian sebagai akibat kecelakaan kerja. Keselamatan kerja yang sangat baik adalah pintu gerbang bagi keamanan para pekerja, keselamatan kerja berhubungan 
dengan semua proses produksi dan distribusi, baik barang maupun jasa (Suma'mur, 2001).

Adapun sasaran pada keselamatan kerja secara terinci yaitu:

a) Mencegah terjadinya kecelakaan di lingkungan kerja

b) Mencegah timbulnya sebuah penyakit akibat kerja

c) Mencegah/mengurangi kematian akibat kerja

d) Mencegah atau mengurangi cacat tetap.

e) Mengamankan material-material, konstruksi, pemakaian, pemilihan bangunan-bangunan, alat-alat kerja, mesin-mesin, instalasi-instalasi.

f) Meningkatkan produktivitas kerja tanpa memeras tenaga kerja dan menjamin setiap kehidupan produktifnya.

g) Mencegah pemborosan bagi tenaga kerja, modal, peralatan dan sumber produksi lainnya sewaktu kerja.

h) Menjamin lingkungan kerja yang sehat, bersih, nyaman dan aman sehingga dapat menimbulkan kegembiraan dan semangat bagi pekerja.

i) Memperlancar dan mengamankan produksi, industri serta bangunan.

Semuanya itu menuju pada sebuah peningkatan taraf hidup dan kesejahteraan umat manusia (Endroyo, 1989).

\section{Kesehatan kerja}

Kesehatan kerja adalah sebuah kondisi badan/tubuh yang terlindungi dan terhindar dari segala macam penyakit atau gangguan yang diakibatkan oleh pekerjaan yang dilaksanakan.

\section{Kecelakaan kerja}

Kecelakaan adalah kejadian yang tidak diharapkan, tidak diinginkan, tidak diramalkan, tidak direncanakan, tidak terduga serta tidak ada unsur kesengajaan yang dapat mengganggu atau merusak kelangsungan yang wajar dari suatu kegiatan dan dapat mengakibatkan suatu luka atau kerusakan pada benda atau peralatan (Sudinarto, 1995).

\section{Tujuan dan Manfaat K3}

Tujuan Keselamatan dan Kesehatan Kerja:

1. Melindungi para pekerja atas hak keselamatan dalam melakukan pekerjaan untuk kesejahteraan hidup.

2. Menjamin keselamatan setiap orang lain yang berada di lingkungan kerja.

3. Sumber produksi dipelihara dan dipergunakan secara baik, aman dan efisien

Manfaat Keselamatan dan Kesehatan Kerja (K3) Secara Ekonomi (Husen, 2011):

1. Menghemat biaya yang tak terduga.

2. Menambah moral dan produktivitas kerja.

3. Mengurangi resiko dan menghemat biaya asuransi pekerja

4. Premiumnya lebih rendah akibat kecelakaan perusahaan yang rendah.

5. Nama dan reputasi yang baik bagi perusahaan dalam hal keselamatan dan kesehatan kerja dapat meningkatkan permintaan pasar terhadap perusahaan.

\section{Sistem Manajemen Keselamatan \& Kesehatan Kerja}

Sistem Manajemen keselamatan dan kesehatan kerja (SMK3) adalah bagian dari sistem manajemen perusahaan secara keseluruhan dalam rangka pengendalian resiko yang berkaitan dengan kegiatan kerja guna terciptanya tempat kerja yang aman dan produktif.

Pengelolaan K3 dapat berjalan dengan baik karena mengikuti tujuan manajemen yang baik, yaitu dimulai dengan proses perencanaan, kemudian penerapan yang didukung oleh sistem pengukuran dan pemantauan dan terakhir dilakukan tinjau ulang secara berkala untuk memperbaiki proses secara berkesinambungan. Bayangkan saja ada perusahaan yang menerapkan K3 tanpa sistem dan bandingkan dengan perusahaan yang menerapkan K3 dengan sistem. Hasilnya pasti akan berbeda

Menurut Permenaker No. 5 tahun 1996, Penerapan SMK3 bertujan untuk:

a. Meningkatkan perlindungan keselamatan dan kesehatan kerja yang terencana, terukur, terstruktur, dan terintregasi

b. Mencegah kecelakaan saat kerja dan penyakit akibat kerja dengan melibatkan unsur manajemen, pekerja/buruh, dan/ serikat pekerja,serikat buruh; serta

c. Menciptakan tempat kerja yang aman, nyaman, bagi tenaga kerja dan efisien untuk mendorong produktifitas,

Adapun elemen sistem dalam menerapkan SMK3 setiap perusahaan wajib melaksanakan :

A. Penetapan kebijakan K3

B. Perencanaan K3

C. Pelaksanaan rencana $\mathrm{K} 3$

\section{METODE PENELITIAN}

Penelitian ini menggunakan teknik pengumpulan data yang dilakukan dengan observasi dan untuk pengambilan sampel di lapangan dilakukan secara purposive. Pengambilan sampel secara purposive adalah cara penarikan sampel yang dilakukan memilih subjek berdasarkan kriteria spesifik yang ditetapkan peneliti.

Penelitian ini dilaksanakan di Kota Surabaya yang merupakan salah satu kota berkembang di Indonesia, tepatnya pada 2 proyek berbeda. Proyek pertama yaitu East Coast Center 2 yang dan proyek yang kedua yaitu Attic Showroom Dharmahusada.

Penelitian ini menggunakan 2 metode sebagai berikut:

1) Kuesioner jenis check list dengan metode skala Guttman, yaitu kuesioner jenis check-list yang menggunakan jawaban bersifat jelas, tegas, dan konsisten, seperti: ya - tidak, sesuai - tidak sesuai, benar - salah, positif - negatif, dan lain sebagainya (Riduwan, 2003). Kuesioner berisi 166 poin pertanyaan mengenai Sistem Manajemen K3 mengacu pada pedoman daftar periksa audit penilaian Penerapan Sistem Manajemen K3 Permenaker nomor 5 tahun 1996 dengan jawaban "sesuai" dan "tidak sesuai”. Kriteria pencapian penerapan seperti pada Tabel 1.

2) Metode yang digunakan dalam penelitian ini adalah metode Fisher exact probability test. Test ini digunakan untuk menguji signifikansi hipotesis komparatif dua sampel kecil independent bila datanya berbentuk nominal untuk sampel yang besar digunakan chi kuadrat $\left(\chi^{2}\right)$. Untuk memudahkan 
perhitungan dalam pengujian hipotesis, maka data hasil pengamatan perlu disusun kedalam Tabel 2 .

Tabel 1. Tingkat Pencapaian Penerapan SMK3

\begin{tabular}{|c|c|}
\hline \multicolumn{2}{|c|}{ Tingkat Pencapaian Penerapan } \\
\hline $0-59 \%$ & Kurang \\
\hline $60-84 \%$ & Baik \\
\hline $85-100 \%$ & Memuaskan \\
\hline
\end{tabular}

Tabel 2 Kontingensi $2 \times 2$

\begin{tabular}{|c|c|c|c|}
\hline Proyek & Sesuai & $\begin{array}{c}\text { Tidak } \\
\text { Sesuai }\end{array}$ & Jumlah \\
\hline I & A & B & A + B \\
\hline II & C & D & C + D \\
\hline \multicolumn{3}{|c|}{ Jumlah } & n \\
\hline
\end{tabular}

Rumus dasar yang digunakan adalah :

$p=\frac{(A+B) !(C+D) !(A+C) !(B+D)}{N ! A ! B ! C ! D !}$.

\section{Proyek I = Sampel I}

Proyek II = Sampel II

Proyek sesuai dan tidak sesuai hanya menunjukkan adanya klasifikasi, misalnya lulus atau tidak lulus, sesuai atau tidak sesuai.

$H 0$ : tidak ada perbedaan (sama)

$H 1$ : ada perbedaan (tidak sama)

$H 0$ diterima apabila nilai $\mathrm{p}$ lebih besar dari taraf kesalahan yang ditetapkan sebesar $\alpha: 0,05$

\section{HASIL PENELITIAN DAN PEMBAHASAN Profil Responden}

Data responden yang diambil adalah nama responden, nama instansi, pendidikan terakhir, jabatan dalam pekerjaan, dan lama bekerja. Responden didominasi lulusan Strata 1 (S1) dengan lama bekerja antara 1-15 tahun. Penjabaran dapat dilihat pada Gambar1,2, dan 3 :

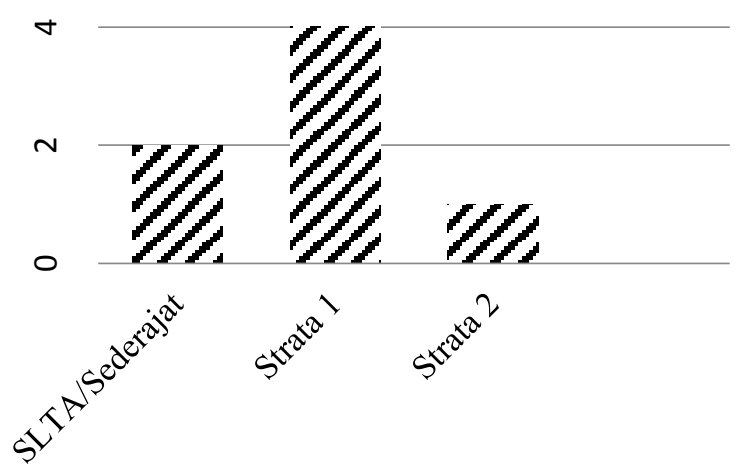

Gambar 1.Tingkat Pendidikan Responden $\checkmark$

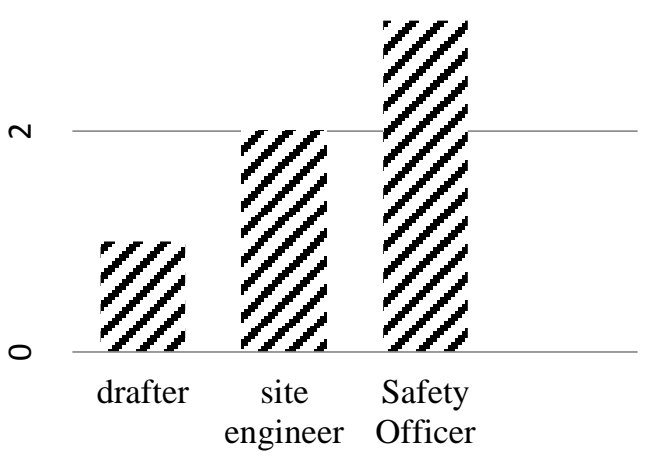

Gambar 2. Jabatan

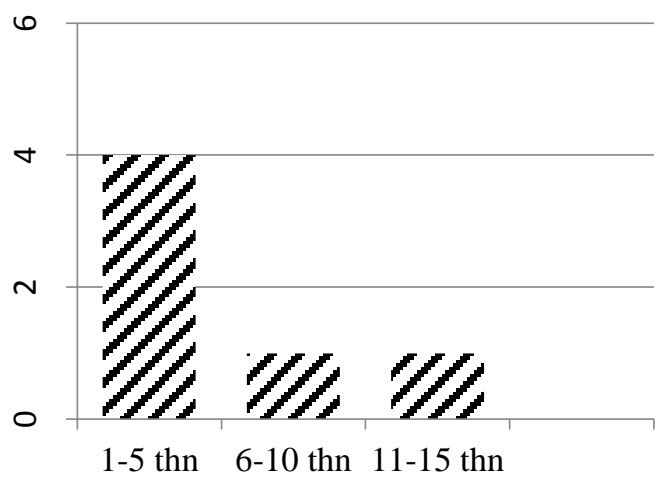

Gambar 3. Pengalaman Bekerja

\section{Evaluasi kinerja SMK3}

Penelitian dengan check list ini mengacu pada Permenaker no.5 tahun 1996 yang terdapat pada halaman lampiran total 166 kriteria. Perhitungan check list ini berdasarkan 12 kriteria induk menggunakan rumus :

\footnotetext{
$\frac{\Sigma \text { Nilai pemenuhan }}{166 \text { kriteria }}$ X $100 \%=$

Persentase Tingkat Pencapaian.
}

Dari hasil check list di 2 proyek yang ditinjau, dilakukan perhitungan tingkat penerapan sistem manajemen keselamatan dan kesehatan kerja berdasarkan hasil kuesioner yang di peroleh dari responden di masingmasing proyek. Hasil perhitungan dapat dilihat pada Gambar 4 dan 5:

Dari 3 responden pada proyek Attic Showroom didapat nilai rata-rata baik yaitu $76,74 \%$, namun ada beberapa ketidaksesuaian yang berpotensi dapat berdampak kurang baik bagi jalannya proyek. Adapun beberapa kriteria yang tidak sesuai dengan Peraturan Permenaker no.5 tahun 1996 yang sama dari ketiga responden tersebut, sebagai berikut :

- Tentang kebijakan SMK3 :

$>$ Keterlibatan dan penjadwalan konsultasi tenaga kerja dengan wakil perusahaan 
didokumentasikan dan disebarluaskan ke seluru tenaga kerja.

$>$ Dibentuk kelompok-kelompok kerja dan dipilih dari wakil-wakil tenaga kerja yang ditunjuk sebagai penanggung jawab K3 ditempat kerjanya dan kepadanya diberikan pelatihan sesuai dengan peraturan perundang-undangan.

$>$ Dibentuk kelompok-kelmpok kerja dan dipilih dari wakil-wakil tenaga kerja yang ditunjuk sebagai penanggung jawab K3 ditempat kerjanya dan diberikan pelatihan sesuai dengan perundang-undangan.

A. Proyek Attic Showroom Dharmahusada

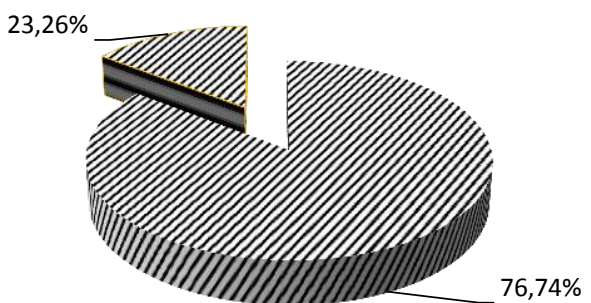

Gambar 4. Hasil Rata-Rata Kuesioner pada proyek Attick Showroom

- Tentang rencana strategi K3

$>$ Rencana strategi K3 sekurangkurangnya berdasarkan tinjauan awal, identifikasi potensi bahay, penilaian, pengendalian rasiko, dan peraturan perundang- undangan serta informasi K3 lain baik dari dalammaupun luar perusahan

$>$ Rencana strategi K3 yang telah ditetapkan digunakan untuk mengendalikan resiko $\mathrm{K} 3$ dengan menetapkan tujuan dan sasaran yang dapat diukur dan menjadi prioritas serta menyediakan sumber daya.

$>$ Rencana kerja dan rencana khusus yang berkaitan dengan produk, proses, proyek atau tempat kerja tertentu telah dibuat dengan menetapkan tujuan dan sasaran yang dapat diukur, menetapkan waktu pencapaian menyediakan sumber daya.

- Tentang pengendalian perancangan dan peninjauan kontrak

Petugas yang berkompeten melakukan verifikasi bahwa perancangan dan/atau modifikasi memenuhi persyaratan K3 yang ditetapkan sebelum penggunaan hasil rancangan.

$>$ Kontrak ditinjau ulang untuk penjamin bahwa pemasok dapat memenuhi persyaratan K3 bagi pelanggan.
B. Proyek East Coast Center 2

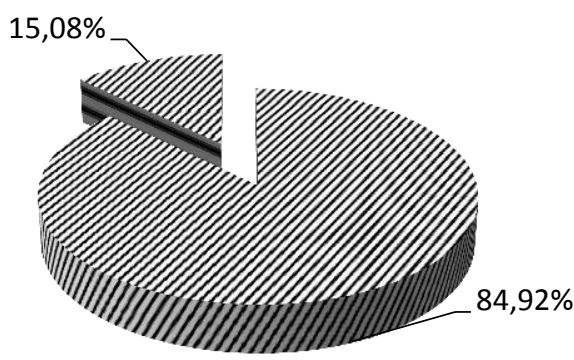

Gambar 5. Hasil Rata-Rata Kuesioner pada proyek East Coast Center 2

Dari 3 responden pada proyek East Coast Center 2 didapat nilai rata-rata memuaskan yaitu $90,56 \%$, namun ada beberapa ketidaksesuaian yang berpotensi dapat berdampak kurang baik bagi jalannya proyek. Adapun beberapa kriteria yang tidak sesuai dengan Permenaker no.5 tahun 1996 yang sama dari ketiga responden tersebut, sebagai berikut :

- Tentang tinjauan dan evaluasi :

> Tinjauan terhadap penerapan SMK3 meliputi kebijakan, perencanaan, pelaksanaan, pemantauan dan evaluasi telah dilakukan, dicatat dan didokumentasikan

$>$ Hasil tinjauan dimasukan dalam perencanaan tindakan manajemen

$>$ Pengurus harus meninjau ulang pelaksanaan SMK3 secara berkala

- $\quad$ Tentang manual SMK3 :

> Manual SMK3 meliputi kebijakan, tujuan, rencana, prosedur SMK3, instruksi kerja, formolir, catatan dan tanggung jawab K3 untuk semua tingkatan dalam perusahaan.

$>$ Terdapat manual khusus berkaitan dengan produk, proses, atau tempat kerja tertentu.

$>$ Manual SMK3 mudah didapat oleh semua personel dalam perusahaan sesuai kebutuhan.

- Tentang Rencana dan Pemulihan Keadaan Darurat

$>$ Prosedur dan pemulihan kondisi tenaga kerja maupun sarana dan peralatan dan peralatan produksi yang mengalami kerusakan telah ditetapkan dan dapat diterapkan sesegera mungkin setelah terjadinya kecelakaan dan penyakit akibat kerja.

- Tentang Pengendalian Bahan Kimia Berbahaya (BKB)

$>$ Perusahan telah mendokumentasikan dan menerapkan prosedur mengenai penyimpangan, penanganan dan pemindahan BKB sesuai dengan persyaratan peraturan perundang-undangan standart dan pedoman teknis yang relevan.

\section{Uji Fhiser Exact Probability}

Analisis Fhiser Exact Probability adalah analisis yang digunakan untuk mengetahui ada tidaknya perbedaan rata- 
rata dua sampel yang tidak berpasangan. Analisis ini merupakan bagian dari statistik non parametrik, sehingga tidak diperlukan data penelitian yang berdistribusi normal.

Adapun hasil analisis uji perbedaan menggunakan metode Fhiser Exact Probability dari 12 kriteria induk dari keusioner pada 2 proyek yang sudah diteliti seoerti pada Tabel 3.

Tabel 3. Uji perbedaan
Nyatakan Hipotesis :

$H 0$ : tidak ada perbedaan antara proyek A \& B (sama) $H 1$ : ada perbedaan antara proyek A \& B (tidak sama)

Taraf kesalahan yang ditetapkan sebesar $\alpha: 0,05$ Jika $\mathrm{p}$ hitung ( nilai fisher exact test) $<\alpha=H 0$ diterima Jika p hitung ( nilai fisher exact test) $>\alpha=H 1$ diterima

\begin{tabular}{|c|c|c|c|c|c|c|}
\hline \multirow[t]{3}{*}{ KRITERIA AUDIT SMK3 } & \multicolumn{4}{|c|}{ PENILAIAN } & \multirow{3}{*}{$\begin{array}{c}\text { Fisher } \\
\text { Exact } \\
\text { Probab } \\
\text { ility } \\
\text { Test }\end{array}$} & \multirow[t]{3}{*}{ KETERANGAN } \\
\hline & \multicolumn{2}{|c|}{ Proyek A } & \multicolumn{2}{|c|}{ Proyek B } & & \\
\hline & Sesuai & $\begin{array}{l}\text { Tidak } \\
\text { Sesuai }\end{array}$ & Sesuai & $\begin{array}{l}\text { Tidak } \\
\text { Sesuai }\end{array}$ & & \\
\hline $\begin{array}{l}\text { Pembangunan dan } \\
\text { Pemeliharaan Komitmen }\end{array}$ & $78,09 \%$ & $24,91 \%$ & $90,17 \%$ & $9,83 \%$ & 0,032 & $\begin{array}{l}\text { Tidak Terdapat } \\
\text { perbedaan }\end{array}$ \\
\hline $\begin{array}{l}\text { Pembuatan dan } \\
\text { Pendokumentasian Rencana } \\
\text { K3 }\end{array}$ & $50 \%$ & $50 \%$ & $77,76 \%$ & $22,24 \%$ & 0,018 & $\begin{array}{l}\text { Tidak Terdapat } \\
\text { perbedaan }\end{array}$ \\
\hline $\begin{array}{l}\text { Pengendalian Perancangan } \\
\text { dan Peninjauan Kontrak }\end{array}$ & $54,15 \%$ & $45,85 \%$ & $100 \%$ & $0 \%$ & 0,08 & Terdapat perbedaan \\
\hline Pengendalian dokumen & $68,07 \%$ & $31,93 \%$ & $100 \%$ & $0 \%$ & 0,06 & Terdapat perbedaan \\
\hline $\begin{array}{l}\text { Penilaian dan Pengendalian } \\
\text { Produk }\end{array}$ & $66,6 \%$ & $33,4 \%$ & $100 \%$ & $0 \%$ & 0,07 & Terdapat perbedaan \\
\hline $\begin{array}{l}\text { Keamanan Bekerja } \\
\text { Berdasarkan SMK3 }\end{array}$ & $83,32 \%$ & $16,68 \%$ & $83,32 \%$ & $16,68 \%$ & 0,026 & $\begin{array}{l}\text { Tidak Terdapat } \\
\text { perbedaan }\end{array}$ \\
\hline Standar Pemantauan & $85,71 \%$ & $14,29 \%$ & $100 \%$ & $0 \%$ & 0,07 & Terdapat perbedaan \\
\hline Pelaporan dan Perbaikan & $100 \%$ & $0 \%$ & $100 \%$ & $0 \%$ & 0,012 & $\begin{array}{l}\text { Tidak Terdapat } \\
\text { perbedaan }\end{array}$ \\
\hline $\begin{array}{l}\text { Pengelolahan material dan } \\
\text { perpindahannya }\end{array}$ & $53,28 \%$ & $46,72 \%$ & $40 \%$ & $60 \%$ & 0,06 & Terdapat perbedaan \\
\hline $\begin{array}{l}\text { Pengumpulan Dan } \\
\text { Penggunaan Data }\end{array}$ & $83,3 \%$ & $16,7 \%$ & $83,3 \%$ & $16,7 \%$ & 0,09 & Terdapat perbedaan \\
\hline Pemeriksaan SMK3 & $88,86 \%$ & $11,14 \%$ & $100 \%$ & $0 \%$ & 0,1 & Terdapat perbedaan \\
\hline $\begin{array}{l}\text { Pengembangan } \\
\text { Keterampilan dan } \\
\text { Kemampuan }\end{array}$ & $85,71 \%$ & $14,29 \%$ & $66,6 \%$ & $33,4 \%$ & 0,08 & Terdapat perbedaan \\
\hline
\end{tabular}

\section{UCAPAN TERIMAKASIH}

Terima kasih atas kerjasamanya dalam penelitian kepada pihak manajemen PT Mitra Konstruksi, dan PT Nusa Raya Cipta Tbk.

\section{KESIMPULAN DAN SARAN} Kesimpulan
1) Proyek konstuksi gedung yang diteliti sudah Menerapakan Sistem Manajemen Keselamtan dan Kesehatan Kerja dengan baik, akan tetapi sepenuhnya belum mencapai $100 \%$. Berdasarkan permenaker no.5 tahun 1996, untuk proyek Attic Showroom Dharmahusada dengan nilai rata-rata tingkat pencapaiannya adalah 76,74\%, kategori baik, sedangkan proyek East Coast Center 2 
mendapat nilai rata-rata tingkat pencapaian $84,92 \%$ kategori memuaskan.

2) Perbandingan antara kedua proyek yang diteliti berdasarkan perbandingan setiap poin pertanyaan menunjukan perbedaan signifikan diukur dari 12 kriteria audit SMK3 menurut Permenaker no.5 tahun 1996 terdapat 8 item yang memiliki perberbedaan yang signifikan dan 4 item yaitu pada poin pembangunan \& pemeliharaan komitmen, poin pembuatan dan pendokumentasian $\mathrm{K} 3$, poin keamanan bekerja berdasarkan SMK3, serta pada poin pelaporan \& perbaikan kekurangan tidak terdapat perbedaan yang signifikan.

\section{DAFTAR PUSTAKA}

Endroyo, Bambang. (1989). Keselamatan Kerja Untuk Teknik Bangunan. IKIP Semarang Press:Semarang.

Feri Harianto (2015). Evaluasi Penerapan Sistem Manajemen Keselamatan dan Kesehaan Kerja (SMK3) pada Proyek Pembangunan Apartemen Gunawangsa MERR Surabaya. SNTEKPAN 2015: $773-780$

Husein, Umar. (2011). Metode Penelitian Untuk Skripsi dan Tesis Bisnis Edisi 11. Jakarta: PT Raja Grafindo Persada

Kurniawan, Yanuar. (2011). Tingkat pelaksanaan Sistem Manajemen Keselamatan dan Kesehatan Kerja di Kota Semarang. Teknik Sipil, FTSP UNNES, Semarang.

Marihot, Tua Efendi Hariandja. (2013). Manajemen Sumber Daya Manusia dan Penikatan produktifitas Pegawai. Jakarta: Grafindo.

Peraturan Menteri Tenaga Kerja nomor 5 tahun 1996 tentang Sistem Manajemen Keselamatan dan Kesehatan Kerja. Jakarta: Menteri Tenaga Kerja Republik Indonesia.

Riduwan, (2003). Dasar-Dasar Statistika. Bandung:Alfabeta

Sugiyono. (2004). Statistik Nonparametris untuk Penelitian. Edisi Keempat: Bandung.

Suma'mur. (2001). Keselamatan Kerja dan Pencagahan Kelakaan. Jakarta:Gunung Agung.

Sudinarto, (1995). Manajemen Konstruksi Profesional, Erlangga, Jakarta. 


\title{
Pengaruh Penerapan Keselamatan Dan Kesehatan Kerja (K3) Serta Lingkungan Kerja Terhadap Produktivitas Kerja Di Surabaya
}

\author{
Ahmad Zainul Arifin ${ }^{1}$ dan Feri Harianto ${ }^{2}$ \\ ${ }^{1,2}$ Jurusan Teknik Sipil, Fakultas Teknik Sipil dan Perencanaan,ITATS, Surabaya \\ E-mail: zain.ipin97@gmail.com ${ }^{1}$,gokbio@yahoo.com ${ }^{2}$
}

\begin{abstract}
ABSTRAK: Semua pekerjaan dituntut agar dapat menghasilkan kualitas yang baik dengan waktu yang telah ditentukan. Salah satunya adalah pekerjaan proyek konstruksi yang saat ini mengalami perkembangan pesat di Indonesia dengan memperhatikan produktivitas kerja. Proyek konstruksi tidak lepas dari keselamatan dan kesehatan kerja yang bisa menunjang suatu pekerja bisa menyelesaikan pekerjaan. Serta lingkungan kerja yang mendukung suatu pekerjaan. Keselamatan dan kesehatan kerja serta lingkungan kerja bisa mempengaruhi produktivitas kerja di suatu proyek konstruksi. Teknik pengambilan penelitian menggunakan metode non probability sampling disertai teknik purposive sampling dengan cara penyebara kuesioner. Responden penelitian adalah mandor, tukang dan pekerja kasar. Penyebaran kuesioner di 3 proyek, yaitu proyek pembangunan Rumah Sakit Katolik St Vicentius Paulo (RKZ), proyek pembangunan Apartmen Puncak Merr, dan proyek pembangunan Apartmen Belleview Manyar. Berdasarkan hasil analisis penelitian menyatakan bahwa variabel keselamatan dan kesehatan kerja (X1) berpengaruh signifikan terhadap produktivitas kerja (Y) dengan nilai (T-statistic=14,487 > 1,96) dan $(P$-values $=0,000<0,05)$. Sedangkan untuk variabel lingkungan kerja (X2) berpengaruh signifikan terhadap produktivitas kerja $(\mathrm{Y})$ dengan nilai $(T$-statistic $=3,962$ $>1,96)$ dan $(P$-values $=0,000<0,05)$.
\end{abstract}

Kata Kunci : Keselamatan dan kesehatan kerja, lingkungan kerja, produktivitas kerja.

\section{PENDAHULUAN}

Perkembangan konstruksi saat ini dituntut agar suatu proyek konstruksi dapat menghasilkan kualitas yang baik dengan waktu yang telah ditentukan. Kualitas yang baik akan memerlukan sumber daya yang baik khususnya manusia. Maju mundurnya suatu perusahaan sangat ditunjang oleh tenaga kerja. Oleh karena itu untuk dapat mewujudkan tenaga kerja yang berkualitas, sehat dan produktif diperlukan adanya suatu pengukuran produktivitas pekerja yang bertujuan untuk menghasilkan produktivitas kerja secara optimal sesuai yang direncanakan. Dalam penerapan keselamatan dan kesehatan kerja harus mendapat perhatian yang sungguhsungguh untuk meningkatkan produktivitas kerja. Hal tersebut sesuai dengan penelitian yang dilakukan oleh (Christina dkk, 2012) yang menyatakan bahwa semakin tinggi budaya (kebiasaan) dalam menerapkan Keselamatan dan Kesehatan Kerja (K3), maka semakin tinggi pula tingkat produktivitas kerja yang dihasilkan.

Menurut Meggison dalam Wahyuni (2018) mendefinisikan bahwa keselamatan kerja adalah keselamatan yang berhubungan dengan aktivitas kerja manusia baik pada industri, manufaktur dan kontruksi, yang melibatkan mesin, peralatan, penanganan material, alat kerja bahan baku dan proses pengolahannya, tempat kerja dan lingkungannya serta cara-cara melakukan pekerjaan, maupun industri jasa yang melibatkan peralatan pembersih gedung, sarana transportasi, dan lainlain.

Menurut Siswanto (2015) menyatakan bahwa keselamatan kerja adalah suatu cara untuk melindungi tenaga kerja dari luka yang disebabkan oleh kecelakaan yang berhubungan dengan pekerjaan. Resiko keselamatan dipengaruhi oleh lingkungan yang menyebabkan kebakaran, patah tulah, kesleo, serta kerugian alat tubuh seperti penglihatan dan pendengaran. Sedangkan kesehatan kerja adalah situasi dimana bebas dari gangguan fisik atau rasa sakit yang disebabkan oleh lingkungan kerja. Resiko kesehatan merupakan fakta- fakta dalam lingkungan kerja yang bekerja melebihi waktu yang ditentukan.

Lingkungan kerja adalah suatu tempat dimana para pekerja sedang melakukan aktivitas pekerjaan. Lingkungan kerja yang baik akan mempunyai dampak yang positif kepada pekerjanya. Hal ini didukung dengan adanya penelitian yang dilakukan oleh Hidayat dkk (2014) yang menyatakan bahwa faktor lingkungan kerja memiliki pengaruh yang cukup signifikan terhadap produktivitas tenaga kerja. Menurut Suardi (2010) menyatakan bahwa lingkungan kesehatan tempat kerja yang kurang baik dapat menurunkan derajat kesehatan dan kinerja para pekerja. Oleh karena itu diadakan upaya pengendalian dengan tujuan untuk dapat mencegah dan mengurangi serta dapat menekan agar hal tersebut tidak terjadi. Didalam kesehatan kerja terdapat kesegaran jasmani dan rohani. Semakin tinggi lingkungan kerja, maka akan semakin tinggi kinerja pada proyek konstruksi. Maksudnya yaitu lingkungan kerja yang aman dan sehat akan meningkatkan kualitas kerja para pekerja sehingga produktivitas para pekerja akan meningkat. Sedangkan penelitian yang dilakukan oleh Faris dan Harianto (2014) menyatakan bahwa lingkungan kerja tidak berpengaruh terhadap kecelakaan kerja sehingga kecelakaan kerja akan menghambat produktivitas kerja.

Dalam upaya untuk mengetahui tingkat produktivitas pekerja di lokasi proyek maka perlu dilakukan sebuah penelitian. Berdasarkan uraian diatas maka dilakukan penelitian untuk mengetahui produktivitas tenaga kerja yang dipengaruhi oleh penerapan keselamatan dan kesehatan kerja (K3) serta lingkungan kerja. Rumusan masalah dalam penelitian ini adalah bagaimana pengaruh keselamatan dan kesehatan kerja terhadap produktivitas kerja dan bagaimana pengaruh lingkungan kerja terhadap produktivitas kerja.

\section{METODE PENELITIAN}

Metode yang digunakan adalah metode survei, Teknik pengambilan sampel penelitian ini dilakukan menggunakan metode non probability sampling disertai 
teknik purposive sampling merupakan teknik pengambilan sampel yang sudah direncanakan oleh peniliti. Maksudnya peneliti tidak memilih responden secara acak melainkan berdasarkan tujuan tertentu dari peneliti. Menurut Ghozali (2015) menyatakan bahwa dalam pemakaian software aplikasi Smart PLS direkomendasikan menggunakan sampel antara 30 sampai dengan 100. Sehingga dalam penelitian ini menggunakan 75 sampel. Pengumpulan data menggunakan penyebaran kuesioner. responden yang dipilih mandor,tukang, dan pekerja kasar. Dalam penelitian ini diambil 3 proyek yang mewakili daerah Surabaya serta sudah menerapkan K3.

1. Proyek pertama adalah proyek pembangunan Rumah Sakit Katolik St Vicentius Paulo (RKZ).

2. Proyek kedua adalah proyek pembangunan Apartmen Puncak Merr.

3. Proyek yang ketiga adalah proyek pembangunan Apartmen Belleview Manyar.

Penelitian ini menggunakan kuesioner yang isinya meliputi variabel Keselamatan dan Kesehatan Kerja \{X1), Lingkungan Kerja (X2), Produktivitas Kerja (Y). Dan terdiri dari beberapa indikator yang meliputi Penyediaan Alat Pelindung Diri (X1.1), Kepemimpinan dan Administrasi (X1.2), Peningkatan kesadaran terhadap K3 (X1.3), Hubungan antar tenaga kerja (X2.1), Suasana kerja (X2.2), Fasilitas tenaga kerja (X2.3), Kualitas kerja (Y1.1), Kuantitas kerja (Y1.2), Ketepatan waktu (Y1.3). Lebih lengkap terdapatpada Gambar 1 terkait kerangka model penelitian.

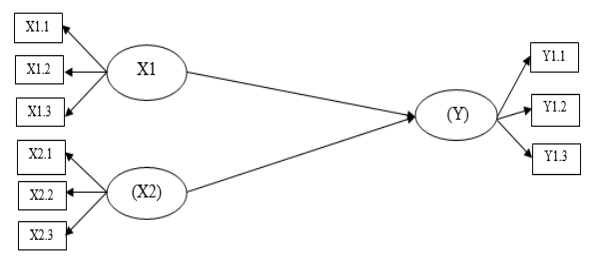

Gambar 1. Kerangka Model Penelitian

\section{HASIL PENELITIAN DAN PEMBAHASAN Frejuensi Penelitian Responden}

Frekuensi penilaian responen untuk pengukuran variabel ini dilakukan dengan penyebaran kuesioner terhadap responden. Penilaian angka yang digunakan untuk pengolahan data merupakan hasil dari pembulatan nilai rata-rata untuk setiap indikator yang memiliki satu atau lebih dari satu pertanyaan, dengan total 3 variabel, 9 indikator dan 30 pertanyaan serta skala pengukuran dari satu sampai dengan lima untuk semua pertanyaan. Tabel 1 menunjukan rekapitulasi penilaian responden terhadap variabel indikator

Dari Tabel 1 akan dilakukan pentabelan ulang untuk menyesuaikan data yang dibutuhkan dengan format csv fungsinya agar data yang didapat bisa dihitung dengan software smart-pls. setelah format penyimpanan data dari excel dirubah menjadi csv maka data tersebut sudah siap untuk diproses dengan menggunakan software smart pls. setelah kita sudah memverifikasi data dalam smart pls maka selanjutnya kita membentuk konstruk dari setiap variabel, Setelah dibentuknya konstruk dari setiap variabel maka tahap selanjutnya dilakukan perhitungan satu persatu dimulai dari sebelum dimoderasi kemudian sesudah dimoderasi dengan tahap calculate ke $p l s$ algoritsm maka akan mengeluarkan hasil dari setiap konstruk yang sudah dibentuk seperti pada Gambar 2 berikut.

Tabel 1 Rekapitulasi Penilaian Responden

\begin{tabular}{|c|c|c|c|c|c|c|c|}
\hline \multirow[t]{2}{*}{ No } & \multirow[t]{2}{*}{ Pertanyaan } & \multicolumn{5}{|c|}{ Jawaban } & \multirow[t]{2}{*}{ Tot } \\
\hline & & 1 & 2 & 3 & 4 & 5 & \\
\hline 1 & $\begin{array}{c}\text { Penyediaan } \\
\text { Alat } \\
\text { Pelindung } \\
\text { Diri (APD) } \\
\text { (X1.1) }\end{array}$ & 0 & 1 & 3 & 55 & 16 & 75 \\
\hline 2 & $\begin{array}{l}\text { Kepemimpina } \\
\mathrm{n} \text { dan } \\
\text { Administrasi } \\
\text { (X1.2) }\end{array}$ & 0 & 10 & 28 & 23 & 14 & 75 \\
\hline 3 & $\begin{array}{l}\text { Peningkatan } \\
\text { kesadaran } \\
\text { terhadap K3 } \\
\text { (X1.3) }\end{array}$ & 0 & 1 & 42 & 23 & 9 & 75 \\
\hline 4 & $\begin{array}{l}\text { Hubungan } \\
\text { antar tenaga } \\
\text { kerja (X2.1) }\end{array}$ & 0 & 1 & 22 & 52 & 0 & 75 \\
\hline 5 & $\begin{array}{l}\text { Suasana kerja } \\
\text { (X2.2) }\end{array}$ & 0 & 2 & 6 & 60 & 2 & 75 \\
\hline 6 & $\begin{array}{l}\text { Fasilitas kerja } \\
\text { tenaga kerja } \\
(\mathrm{X} 2.3)\end{array}$ & 0 & 0 & 0 & 48 & 27 & 75 \\
\hline 7 & $\begin{array}{l}\text { Kualitas kerja } \\
\text { (Y1.1) }\end{array}$ & 0 & 2 & 18 & 42 & 3 & 75 \\
\hline 8 & $\begin{array}{l}\text { Kuantitas } \\
\text { kerja (Y1.2) }\end{array}$ & 0 & 1 & 33 & 28 & 13 & 75 \\
\hline 9 & $\begin{array}{l}\text { Ketepatan } \\
\text { waktu (Y1.3) }\end{array}$ & 0 & 0 & 17 & 20 & 38 & 75 \\
\hline \multicolumn{2}{|c|}{ Total Jawaban } & 0 & 18 & 169 & 351 & 122 & \\
\hline
\end{tabular}

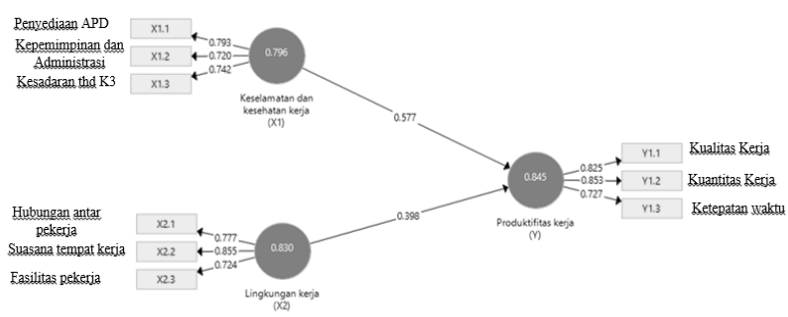

Gambar 2. Konstruk dari setiap variabel

Dari hasil perhitungan smart pls maka didapat hasil seperti Gambar 2, dari hasil tersebut bisa diketahui uji validitas convergent, validitas discriminant dan uji reliabilitas untuk uji permodelan outer model, mengetahui hasil $R$-square, effect size dan uji signifikan untuk uji permodelan inner model. untuk lebih jelas tentang analisis data yang dihasilkan dari uji permodelan maka akan dijelaskan dalam pengertian dibawah ini

\section{Menghitung Pengukuran Outer Model}

\section{a. Uji Validitas Convergent}

Validitas Convergent adalah hasil yang didapat unutk menunjukkan nilai setiap indikator yang mewakili atau 
endasari variabel laten tersebut. berikut adalah hasil dari perhitungan data dengan uji validitas convergent pada Tabel 2 dan 3.

Tabel 2. Nilai Outer Loading

\begin{tabular}{|c|c|c|c|c|}
\hline Variabel & $\mathbf{X 1}$ & $\mathbf{X 2}$ & $\mathbf{Y}$ & Keterangan \\
\hline $\mathbf{X 1 . 1}$ & 0.861 & & & Valid \\
\hline $\mathbf{X 1 . 2}$ & 0.843 & & & Valid \\
\hline $\mathbf{X 1 . 3}$ & 0.714 & & & Valid \\
\hline $\mathbf{X 2 . 1}$ & & 0.867 & & Valid \\
\hline $\mathbf{X 2 . 2}$ & & 0.773 & & Valid \\
\hline $\mathbf{X 2 . 3}$ & & 0.876 & & Valid \\
\hline $\mathbf{Y 1 . 1}$ & & & 0.812 & Valid \\
\hline $\mathbf{Y 1 . 2}$ & & & 0.876 & Valid \\
\hline $\mathbf{Y 1 . 3}$ & & & 0.853 & Valid \\
\hline
\end{tabular}

Tabel 3. Nilai AVE

\begin{tabular}{|l|c|}
\hline \multicolumn{1}{|c|}{ Variabel } & AVE \\
\hline $\begin{array}{l}\text { Keselamatan dan Kesehatan } \\
\text { Kerja }\end{array}$ & 0.654 \\
\hline Lingkungan Kerja & 0.706 \\
\hline Produktifitas Kerja & 0.718 \\
\hline
\end{tabular}

Berdasarkan hasil dari Tabel 2 dan 3 menunjukkan bahwa nilai variabel indikator dengan variabel laten memiliki nilai refleksi tinggi dan mempunyai hasil yang memenuhi syarat perhitungan outer loading nilai harus $>0,70$.

Variabel Keselamatan dan Kesehatan Kerja (X1) diukur dengan 3 indikator yaitu indikator pertama penyediaan Alat Pelindung Diri (APD) (X1.1) dengan hasil 0,861, kedua kepemimpinan dan administrasi (X1.2) dengan hasil 0,843 , ketiga kesadaran terhadap K3 (X1.3) dengan hasil 0,714.

Variabel lingkungan kerja (X2) diukur dengan 3 indikator yaitu indikator pertama hubungan antar pekerja (X2.1) dengan hasil 0,867, kedua adalah indikator suasana tempat kerja (X2.2) dengan hasil 0,773, ketiga adalah indikator fasilitas kerja (X2.3) dengan hasil 0,876.

Variabel produktivitas kerja (Y) diukur dengan 3 indikator yaitu indikator pertama kualitas kerja (Y1.1) dengan hasil 0,812, kedua adalah indikator kuantitas kerja (Y1.2) dengan hasil 0,876, ketiga adalah indikator ketepatan waktu (Y1.3) dengan hasil 0,853.

Dan untuk nilai AVE pada tabel 4.6 didapat hasil dengan keselamatan dan kesehatan kerja (X1) sebesar 0,654, suasana kerja (X2) sebesar 0,706, dan produktivitas kerja (Y) sebesar 0,718. Dari semua nilai yang dihasilkan AVE memenuhi syarat > 0,50 sehingga semua indikator dalam penelitian ini dinyatakan valid.

\section{b. Uji Validitas Discriminant}

Uji Validitas Discriminant merupakan nilai yang didapat digunakan untuk ukuran konstruk dari indikator satu dengan indikator yang lain itu berbeda. Hasil dari perhitungan data dengan uji validitas discriminant dapat dilihat pada Tabel 4,5 dan 6 .

Tabel 4. Latent Variable Correlations

\begin{tabular}{|c|c|c|c|}
\hline & $\begin{array}{c}\text { Keselamatan dan } \\
\text { kesehatan kerja } \\
\text { (X1) }\end{array}$ & $\begin{array}{c}\text { Lingkungan } \\
\text { Kerja (X2) }\end{array}$ & $\begin{array}{c}\text { Produktifitas } \\
\text { Kerja (Y) }\end{array}$ \\
\hline X1 & 0.809 & & \\
\hline X2 & 0.297 & 0.84 & \\
\hline Y & 0.821 & 0.464 & 0.847 \\
\hline
\end{tabular}

Tabel 5. Nilai Akar AVE

\begin{tabular}{|l|c|c|}
\hline \multicolumn{1}{|c|}{ Variabel } & AVE & Akar AVE \\
\hline $\begin{array}{l}\text { Keselamatan dan } \\
\text { Kesehatan Kerja }\end{array}$ & 0.654 & 0.8087027 \\
\hline $\begin{array}{l}\text { Lingkungan } \\
\text { Kerja }\end{array}$ & 0.706 & 0.8402381 \\
\hline $\begin{array}{l}\text { Produktifitas } \\
\text { Kerja }\end{array}$ & 0.718 & 0.8473488 \\
\hline
\end{tabular}

Tabel 6. Nilai Cross Loading

\begin{tabular}{|c|c|c|c|}
\hline Variabel & $\begin{array}{c}\text { Keselamatan } \\
\text { dan } \\
\text { Kesehatan } \\
\text { Kerja (X1) }\end{array}$ & $\begin{array}{c}\text { Lingkungan } \\
\text { Kerja (X2) }\end{array}$ & $\begin{array}{c}\text { Produktifitas } \\
\text { kerja (Y) }\end{array}$ \\
\hline X1.1 & $\mathbf{0 . 8 6 1}$ & 0.430 & 0.683 \\
\hline X1.2 & $\mathbf{0 . 8 4 3}$ & 0.325 & 0.749 \\
\hline $\mathbf{X 1 . 3}$ & $\mathbf{0 . 7 1 4}$ & -0.111 & 0.540 \\
\hline $\mathbf{X 2 . 1}$ & 0.245 & $\mathbf{0 . 8 6 7}$ & 0.444 \\
\hline $\mathbf{X 2 . 2}$ & 0.179 & $\mathbf{0 . 7 7 3}$ & 0.311 \\
\hline $\mathbf{X 2 . 3}$ & 0.314 & $\mathbf{0 . 8 7 6}$ & 0.398 \\
\hline Y1.1 & 0.58 & 0.515 & $\mathbf{0 . 8 1 2}$ \\
\hline Y1.2 & 0.648 & 0.344 & $\mathbf{0 . 8 7 6}$ \\
\hline Y1.3 & 0.828 & 0.338 & $\mathbf{0 . 8 5 3}$ \\
\hline
\end{tabular}

Berdasarkan hasil pada Tabel 45 dan 6 hasil dari cross loading diatas dapat dinyatakan bahwa masingmasing indikator memiliki nilai cross loading > 0,70 terhadap variabel lain. Hal ini dilihat dari hasil korelasi konstruk (hubungan antar variabel) dari keselamatan dan kesehatan kerja (K3) X1.1=0,861 X1.2=0,843 $\mathrm{X} 1.3=0,714$, korelasi konstruk dari lingkungan kerja $\mathrm{X} 2.1=0,867, \mathrm{X} 2.2=0,773, \mathrm{X} 2.3=0,876$, korelasi konstruk dari produktivitas kerja lainnya $(\mathrm{Y} 1 \rightarrow \mathrm{Y} 1.1, \mathrm{Y} 1.2, \mathrm{Y} 1.3)$ dengan nilai $\mathrm{Y} 1.1=0,812, \mathrm{Y} 1.2=0,876, \mathrm{Y} 1.3=0,853$, sehingga variabel indikator bisa dikatakan valid karena korelasi indikator konstruknya lebih tinggi dari pada korelasi/hubungan indikator ke konstruk yang lain.

\section{c. Uji Reliabilitas}

Uji reliabilitas adalah merupakan tahap terakhir dalam permodelan outer model yang menjelaskan konsistensi dari semua hasil uji pengukuran yang sudah dilakukan ini. Hasil dari perhitungan data dengan uji reliabilitas dapat dilihat pada Tabel 7. 
Tabel 7. Nilai Cronbachs Alpha dan Composite Reliability

\begin{tabular}{|l|c|c|c|}
\hline \multicolumn{1}{|c|}{ Permodelan } & $\begin{array}{l}\text { Cronbac } \\
\text { hs Alpha }\end{array}$ & $\begin{array}{l}\text { Composite } \\
\text { Reliability }\end{array}$ & Keterangan \\
\hline $\begin{array}{l}\text { Keselamatan dan } \\
\text { Kesehatan Kerja } \\
\text { (X1) }\end{array}$ & 0.735 & 0.849 & Reliabel \\
\hline $\begin{array}{l}\text { Lingkungan Kerja } \\
\text { X2) }\end{array}$ & 0.793 & 0.878 & Reliabel \\
\hline $\begin{array}{l}\text { Produktifitas } \\
\text { Kerja(Y) }\end{array}$ & 0.805 & 0.844 & Reliabel \\
\hline
\end{tabular}

\section{Menghitung Pengukuran Inner Model}

Inner model adalah pengukuran yang dilakukan untuk mengetahui pengaruh antara variabel laten satu dengan variabel laten lainnya. Dalam uji ini mencari nilai $R$ square, kemudian untuk mengetahui nilai signifikan dari setiap pengaruh variabel maka akan dilakukan proses bootstrapping dengan nilai $R$ Square terdapat pada Tabel 8 ..

Tabel 8. Nilai $R$-Square

\begin{tabular}{|c|c|c|}
\hline Variabel & R-Square & $\begin{array}{c}\text { R-Square } \\
\text { Adjusted }\end{array}$ \\
\hline Produktifitas Kerja & 0.728 & 0.72 \\
\hline
\end{tabular}

Berdasarkan hasil pada tabel 8 diatas didapat nilai $R$ Square sebesar 0,728. Hal ini menunjukkan bahwa variabel keselamatan dan kesehatan kerja (X1), dan lingkungan kerja (X2) dapat berpengaruh terhadap produktifitas kerja (Y), dimana variabel keselamatan dan kesehatan kerja (X1), dan lingkungan kerja (X2) mampu menjelaskan produktivitas kerja (Y) sebesar $72,8 \%$.

Tabel 9. Hasil dari perhitungan smart pls

\begin{tabular}{|c|c|c|c|c|c|}
\hline $\begin{array}{c}\text { variabel laten } \\
\text { dengan } \\
\text { variabel laten }\end{array}$ & $\begin{array}{c}\text { Origin } \\
\text { al } \\
\text { Sample }\end{array}$ & $\begin{array}{c}\text { Sample } \\
\text { Mean } \\
(\boldsymbol{M})\end{array}$ & $\begin{array}{c}\text { Standard } \\
\text { Deviatio } \\
\boldsymbol{n} \\
(\text { STDEV })\end{array}$ & $\begin{array}{c}\boldsymbol{T} \text { - } \\
\text { Statisti } \\
\boldsymbol{c}\end{array}$ & $\begin{array}{c}\boldsymbol{P} \text { Va } \\
\text { lue }\end{array}$ \\
\hline $\begin{array}{c}\text { K3 (X1) } \rightarrow \\
\text { Produktifitas } \\
\text { kerja (Y) }\end{array}$ & 0.750 & 0.751 & 0.052 & 14.487 & 0 \\
\hline $\begin{array}{c}\text { Lingkungan } \\
\text { kerja (X2) } \rightarrow \\
\text { Produktifitas } \\
\text { kerja (Y) }\end{array}$ & 0.242 & 0.242 & 0.061 & 3.962 & 0 \\
\hline
\end{tabular}

Hasil dari pengujian hipotesis menggunakan permodelan outer model dan inner model didapatkan penjelasan pengaruh masing-masing variabel sebagai berikut:

Pada hasil pengujian yang didapat dari tabel 8 didapatkan nilai original sample keselamatan dan kesehatan kerja (X1) $\rightarrow$ Produktivitas kerja (Y) sebesar 0,750 (positif) sehingga menunjukkan bahwa hubungan antar variabel positif. Nilai untuk T-statistic sebesar 14,487, hal ini menjelaskan bahwa nilai $T$-statistic $>1,96$. Untuk hasil dari $P$-values didapatkan nilai sebesar 0,000, hal ini menjelaskan bahwa $P$-values signifikan karena $<0,05$. Dari semua hasil yang sudah didapat bisa dinyatakan bahwa keselamatan dan kesehatan kerja (X1) berpengaruh positif terhadap produktivitas kerja (Y). Sehingga dapat dijelaskan bahwa semakin tinggi penerapan keselamatan dan kesehatan kerja dalam proyek bisa berpengaruh dalam produktivitas kerja.

Menurut penelitian dari Christina dkk (2012) mengatakan bahwa semakin tinggi budaya keselamatan dan kesehatan kerja, maka semakin tinggi pula tingkat produktivitas kerja yang dihasilkan oleh suatu proyek konstruksi. Ini berarti bisa dijelaskan bahwa keselamatan dan kesehatan kerja memang sangat berpengaruh terhadap tingkat produktivitas kerja. Hal tersebut sesuai dengan hasil dari penelitian ini.

Pada hasil pengujian yang didapat dari tabel 8 didapat nilai original sample lingkungan kerja (X2) $\rightarrow$ produktivitas kerja (Y) sebesar 0,242 (positif) sehingga menunjukkan bahwa hubungan antar variabel positif. Nilai T-statistic sebesar 3,962, hal ini menjelaskan bahwa nilai $T$-statistic $>1,96$. Untuk hasil $P$-values sebesar 0,000, hal ini menjelaskan bahwa $P$-values signifikan karena $<0,05$. Dari semua hasil yang didapatkan bisa diartikan bahwa lingkungan kerja berpengaruh terhadap produktivitas kerja.

Menurut penelitian dari Hidayat dkk (2005) yang menyatakan bahwa faktor lingkungan kerja memiliki pengaruh yang cukup signifikan terhadap produktivitas kerja. Ini berarti bisa dijelaskan bahwa lingkungan kerja memang berpengaruh terhadap produktivitas kerja. Hal tersebut sesuai dengan hasil dari penelitian ini.Menurut Faris dan Harianto (2014) menyatakn bahwa lingkungan kerja tidak berpengaruh terhadap kecelakaan kerja yang berdampak akan produktivitas kerja dikarenakan lingkungan kerja yang kurang kondusif. Namun berbeda dengan penelitian ini yang menyatakan bahwa lingkunga kerja berpengaruh positif terhadap produktivitas kerja karena lingkungan kerja yang aman.

\section{UCAPAN TERIMAKASIH}

Terima kasih atas kerjasamanya dalam penelitian kepada pihak manajemen PT MULTIKON, PT PULAUINTAN, dan PT WIKA.

\section{KESIMPULAN DAN SARAN Kesimpulan}

Berdasarkan hasil penelitian dan pembahasan dapat diambil beberapa kesimpulan sebagai berikut:

1. Variabel keselamatan dan kesehatan kerja (X1) berpengaruh signifikan terhadap variabel produktivitas kerja (Y) karena nilai T-statistic 14,487 > 1,96. Semakin tinggi penerapan keselamatan dan kesehatan kerja dalam proyek maka semakin tinggi pula tingkat produktivitas kerja yang dihasilkan.

2. Variabel lingkungan kerja (X2) berpengaruh signifikan terhadap variabel produktivitas kerja (Y) karena nilai $T$-statistic 3,962 > 1,96. Semakin tinggi tingkat lingkungan kerja pada proyek maka semakin tinggi tingkat produktivitas kerja yang dihasilkan.

\section{Saran}

1. Disarankan bagi perusahan lebih memperhatikan dan menjalankan tentang prosedur keselamatan dan kesehatan kerja serta lingkungan kerja yang sudah ditetapkan harus diterapkan. Karena hal ini bisa meningkatkan produktivitas kerja di lokasi proyek. 
2. Disarankan kepada peneliti selanjutnya untuk meneliti variabel-variabel yang tidak diteliti dalam penelitian ini seperti fasilitas kerja, lingkungan disekitar proyek dan lain-lain yang berhubungan dengan kondisi dan jenis proyek yang akan dilakukan sebuah penelitian.

\section{DAFTAR PUSTAKA}

Christina, dkk. 2012. Pengaruh Budaya Keselamatan dan Kesehatan Kerja (K3) terhadap Kinerja Proyek Konstruksi. Jurnal Rekayasa Sipil. Vol 6 (1): 8395.

Faris, Iqbal Al dan Harianto, Feri. 2014. Pengaruh Perilaku Tenaga Kerja dan Lingkungan Kerja yang Dimoderasi Faktor Pengalaman Kerja dan Tingkat Pendidikan Terhadap Kecelakaan Kerja Konstruksi Di Surabaya. Skripsi tidak diterbitkan. Surabaya: Fakultas Teknik Sipil Institut Adhi Tama Surabaya.

Ghozali, Dkk. 2014. Partial Lest Squares Konsep Teknik Dan Aplikasi Menggunakan Program SmartPLS 3.0 Untuk Penelitian Empiris. Universitas Dipenogoro Semarang: Semarang.

Hidayat, dkk. 2014. Pengaruh Penerapan Keselamatan dan Kesehatan Kerja (K3) terhadap Kualitas Hasil Kerja dan Kenyamanan Pekerja pada Proyek Pembangunan Gedung Di Probolinggo. Jurnal Info Manajemen Proyek. Vol 5: 27-36.

Siswanto, Bayu Indra. 2015. Pengaruh Pelaksanaan Keselamatan dan Kesehatan Kerja Terhadap Produktivitas Kerja Karyawan Pada PT. Pembangunan Perumahan Tbk Cabang Kalimantan Di Balikpapan. Jurnal Administrasi Bisnis. Vol 3 (1): $68-82$.

Suardi, Rudi. 2007. Sistem Manajemen Keselamatan dan Kesehatan Kerja. Jakarta: PPM.

Wahyuni, dkk. 2018. Pengaruh Keselamatan dan Kesehatan Kerja (K3) terhadap Produktivitas Kerja Karyawan pada PT. Kutai Timber Indonesia. Jurnal Pendidikan Ekonomi. Vol 12 (1): 99-104. 
Jurnal Rekayasa Tenik Sipil Universitas Madura Vol. 5 No.1 Juni 2020 ISSN 2527-5542

Halaman Ini Sengaja Dikosongkan 


\title{
Analisa Kualitas Pekerjaan Dinding Dengan Bata Merah dan Bata Ringan \\ (Studi Kasus : Perumahan Type 46 Di Kabupaten Pamekasan)
}

\author{
Dedy Asmaroni ${ }^{1}$ dan Ach. Rofii ${ }^{2}$ \\ ${ }^{I}$ Teknik Sipil, Fakultas Teknik, Universitas Madura, Pamekasan \\ ${ }^{2}$ Praktisi, CV. Windo Abadi, Sampang \\ E-mail: E-mail: dedyasmaroni@unira.ac.id, yopiklagi@gmail.com.
}

\begin{abstract}
Abstrak : Perencanaan bangunan, tidak lepas dari elemen vertikal yang disebut juga dinding. Pada umumnya suatu bangunan sering direncanakan menggunakan dinding batu bata merah. Akan tetapi akhir-akhir ini muncul alternatif baru pengganti bata merah sebagai dinding yaitu berupa batu bata ringan, baik pada bangunan tingkat tinggi atau bangunan sederhana. Inovasi bata ringan ini digunakan karena lebih cepat dan lebih murah namun memiliki kekurangan dari segi mutu dan ketahanan jika dibandingkan dengan bata merah. Berdasarkan uraian tersebut, tujuan peneliti ini adalah untuk mendapatkan analisa kualitas pekerjaan dinding bata merah dan bata ringan serta mengetahui faktor yang paling dominan antara penggunaan bata ringan dan bata merah pada perumahan type 46 di Pamekasan. Dengan menggunakan program SPSS (Statistical Product and Service Solution) dapat membandingkan nilai koefisien beta masing- masing variabel dapat diketahui variabel metode pelaksanaan memiliki nilai koefisien beta terbesar yaitu 0,380 . Dari hasil diatas dapat disimpulkan bahwa Kelima variabel berpengaruh terhadap variabel (Y) yaitu kualitas pekerjaan. Kualitas bata ringan lebih bagus digunakan pada pasangan dinding pembangunan perumahan. Faktor yang paling dominan pengaruhnya dalam pekerjaan dinding terhadap pembangunan perumahan type 46 di Pamekasan adalah metode pelaksanaan dengan nilai beta sebesar 0,380 .
\end{abstract}

Kata Kunci : Batu Bata Merah, Batu Bata Ringan, Kualitas Pekerjaan Dinding

\section{PENDAhuluan}

Tempat tinggal merupakan bagian dari kehidupan yang senantiasa harus diperjuangkan dan diperhatikan dengan lebih cermat. Pembangunan rumah dan gedung baik yang bertingkat maupun tidak bertingkat telah banyak dilaksanakan di berbagai sudut kota, bahkan sampai pelosok desa. Banyaknya pembangunan tempat tinggal dan gedung perkantoran tersebut membawa sisi positif bagi dunia konstruksi pada khususnya.

Perencanaan bangunan, baik itu tingkat tinggi ataupun bangunan sederhana tidak lepas dari adanya elemen vertikal yang biasa kita sebut dinding. Dinding adalah elemen vertikal ruang dan merupakan bagian non struktur yang menjadi alat penyekat antar ruang maupun penyekat antar bagian dalam gedung dengan bagian luar gedung.

Pada umumnya dalam merencanakan atau membuat suatu bangunan menggunakan dinding batu bata merah. Akan tetapi dengan kemajuan ilmu pengetahuan dan teknologi ini terjadi perkembangan pada material dinding. Munculnya bata ringan yang merupakan material baru sebagai alternatif pengganti batu bata merah pada konstruksi dinding. Baik itu bangunan tingkat tinggi atau bangunan sederhana. Inovasi bata ringan ini dikenal karena lebih cepat dan lebih murah namun memiliki kekurangan dari segi mutu dan ketahanan jika dibandingkan dengan bata merah. Hal ini menjadi dasar penelitian, yaitu dengan membandikan dinding yang disusun dengan batu bata merah dan dinding yang dibuat dengan menggunakan batu bata ringan. Penelitian dilakukan dengan membandingkan kedua cara konstruksi tersebut dilihat dari segi biaya dan waktu.

Berdasarkan uraian teori diatas, maka penulis tertarik mengadakan penelitian terkait permasalahan tersebut

\section{METODE PENELITIAN}

Metode penelitian pada penlitian ini dimulai pada identifikasi masalah, dilanjutkan dengan mengumpulkan literatur atau pustaka sebagai acuan atau referensi. Setelah itu dianjutkan dengan penentuan variabel, penyusunan dan penyebaran kuesioner sehingga didapatkan data yang diambil dari dua perumahan dengan rincian yaitu, dua orang owner atau developer, dua orang mandor, dan pekerja sebanyak dua puluh orang. Setelah data tersebut didapatkan selanjutnya diolah menggunakan aplikasi SPPS dan untuk lebih jelas terkait alur penelitian terdapat pada Gambar 1.

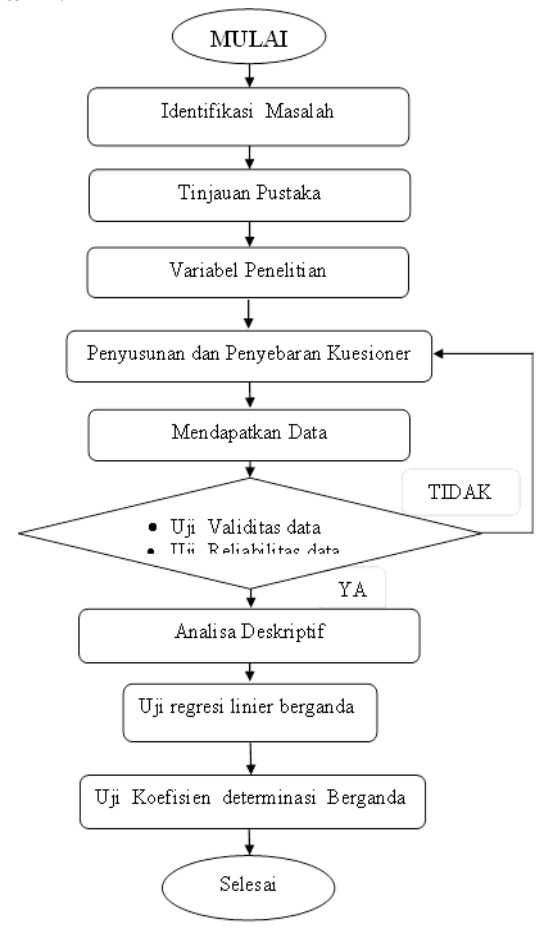

Gambar 1. Diagram Alir Penelitian 


\section{1) Langkah-Langkah Penentuan Strategi} Penelitian

- Melihat nilai hasil analisa regresi linier berganda terhadap variabel-variabel independent yang memiliki nilai signifikan $>0,05$

- Menentukan variabel independent yang paling berpengaruh dominan terhadap kualitas pekerjaan. Variabel yang paling dominan adalah variabel yang paling berpengaruh signifikan dan nilai koefisien $\beta$ yang paling besar.

- Dari hasil data diatas, maka dapat disimpulkan kriteria strategi terhadap variabel-variabel.

\section{PEMBAHASAN}

1) Uji Validitas

\section{- Informasi Statistik Biaya (X1)}

Tabel 1 dibawah ini merupakan hasil rekapan pearson correlate pada data informasi statistik biaya (X1).

Tabel 1 Data Informasi Statistik

\begin{tabular}{|c|c|c|c|c|c|}
\hline $\begin{array}{c}\text { Varia } \\
\text { bel }\end{array}$ & $\begin{array}{c}\text { Indikat } \\
\text { or }\end{array}$ & $\begin{array}{c}\text { Koefi } \\
\text { sien } \\
\text { Korel } \\
\text { asi }\end{array}$ & $\begin{array}{c}\text { Nilai } \\
\mathrm{r} \\
\text { Tabel }\end{array}$ & $p$-value & Hasil \\
\hline $\begin{array}{c}\text { Biaya } \\
\text { (X1) }\end{array}$ & X1.A1 & 0,756 & 0,404 & 0,000 & Valid \\
\cline { 2 - 6 } & X1.A2 & 0,786 & 0,404 & 0,000 & Valid \\
\hline
\end{tabular}

Dari Tabel 1 didapat data biaya (X1), pertanyaan X1.A1 dan X1.A2 diperoleh nilai koefisien korelasi lebih besar dari $r$ tabel yaitu 0,404 sehingga dapat diputuskan bahwa data terima hipotesa nol dan kesimpulannya yaitu data yang diperoleh telah valid.

\section{- Informasi Statistik Waktu (X2)}

Tabel 2 dibawah ini merupakan hasil rekapan pearson correlate pada data informasi statistik Waktu (X2).

Tabel 2 Data Informasi Statistik Waktu (X2)

\begin{tabular}{|c|c|c|c|c|c|}
\hline $\begin{array}{c}\text { Varia } \\
\text { bel }\end{array}$ & $\begin{array}{c}\text { Indikat } \\
\text { or }\end{array}$ & $\begin{array}{c}\text { Koefis } \\
\text { ien } \\
\text { Korela } \\
\text { si }\end{array}$ & $\begin{array}{c}\text { Nilai r } \\
\text { Tabel }\end{array}$ & $\begin{array}{c}p- \\
\text { value }\end{array}$ & Hasil \\
\hline $\begin{array}{c}\text { Wakt } \\
\text { u } \\
(\mathrm{X} 2)\end{array}$ & X2.B1 & 0,829 & 0,404 & 0,000 & Valid \\
\cline { 2 - 6 } & X2.B2 & 0,800 & 0,404 & 0,000 & Valid \\
\hline
\end{tabular}

Dari Tabel 2 dihasilkan data waktu (X2), pertanyaan X2.B1 dan X2.B2 diperoleh nilai koefisien korelasi lebih besar dari $r$ tabel yaitu 0,404 sehingga dapat diputuskan bahwa data terima hipotesa nol dan kesimpulannya yaitu data yang diperoleh telah valid.

- Data Informasi Statistik Metode Pelaksanaan (X3)

Tabel 3 dibawah ini merupakan hasil rekapan pearson correlate pada data informasi statistik Metode Pelaksanaan (X3).

Tabel 3 Data Informasi Statistik Metode Pelaksanaan (X3).

\begin{tabular}{|c|c|c|c|c|c|}
\hline Variabel & $\begin{array}{c}\text { Indi } \\
\text { kato } \\
\mathrm{r}\end{array}$ & $\begin{array}{c}\text { Koefi } \\
\text { sien } \\
\text { Korel } \\
\text { asi }\end{array}$ & $\begin{array}{c}\text { Nilai } \mathrm{r} \\
\text { Tabel }\end{array}$ & $\begin{array}{c}p- \\
\text { valu } \\
e\end{array}$ & Hasil \\
\hline $\begin{array}{c}\text { Metode } \\
\text { Pelaksana } \\
\text { an } \\
(\mathrm{X} 3)\end{array}$ & $\begin{array}{c}\mathrm{X} 3 . \\
\mathrm{C} 1\end{array}$ & 1,000 & 0,404 & $\begin{array}{c}0,00 \\
0\end{array}$ & Valid \\
\hline
\end{tabular}

- Data Informasi Statistik Kerapian (X4)

Tabel 4 dibawah ini merupakan hasil rekapan pearson correlate pada data informasi statistik kerapian (X4) menggunakan software SPSS.

Tabel 4 Data Informasi Statistik Kerapian (X4)

\begin{tabular}{|c|c|c|c|c|}
\hline Variabel & Indikator & $\begin{array}{c}\text { Koefisien } \\
\text { Korelasi }\end{array}$ & $\begin{array}{c}\text { Nilai } \\
\mathrm{r} \\
\text { Tabel }\end{array}$ & Hasil \\
\hline $\begin{array}{c}\text { Kerapian } \\
\text { (X4) }\end{array}$ & X4.D1 & 1,000 & 0,404 & Valid \\
\hline
\end{tabular}

Tabel 4.4 merupakan hasil pengujian validitas Kerapian (X4) menggunakan software SPSS. Dari data Kerapian (X4), pertanyaan X4.D1 diperoleh nilai koefisien korelasi lebih besar dari $\mathrm{r}$ tabel yaitu 0,404 sehingga dapat diputuskan bahwa data terima hipotesa nol dan kesimpulannya yaitu data yang diperoleh telah valid.

\section{- Data Informasi Statistik Dampak Lingkungan (X5)}

Tabel 5 dibawah ini merupakan hasil rekapan pearson correlate pada data informasi statistik Dampak Lingkungan (X5) menggunakan software SPSS.

Tabel 4.5 Data Informasi Statistik Dampak Lingkungan (X5)

\begin{tabular}{|c|c|c|c|c|}
\hline Variabel & Indikator & $\begin{array}{c}\text { Koefisien } \\
\text { Korelasi }\end{array}$ & $\begin{array}{c}\text { Nilai } \\
\mathrm{r} \\
\text { Tabel }\end{array}$ & Hasil \\
\hline \multirow{2}{*}{$\begin{array}{c}\text { Pengala } \\
\text { man (X5) }\end{array}$} & X5.E1 & 0,670 & 0,404 & Valid \\
\cline { 2 - 5 } & X5.E2 & 0,888 & 0,404 & Valid \\
\hline
\end{tabular}

Tabel 5 merupakan hasil pengujian validitas Dampak Lingkungan (X5) menggunakan software SPSS. Dari data Dampak Lingkungan (X5), pertanyaan X5.E1 dan X5.E2 diperoleh nilai koefisien korelasi lebih besar dari $r$ tabel yaitu 0,404 sehingga dapat diputuskan bahwa data terima hipotesa nol dan kesimpulannya yaitu data yang diperoleh telah valid.

\section{- Data Informasi Statistik Kualitas Pekerjaan (Y)}

Tabel 6 dibawah ini merupakan hasil rekapan pearson correlate pada data informasi statistik kualitas pekerjaan (Y) menggunakan software SPSS.

Tabel 6 Data Informasi Statistik Kualitas Pekerjaan (Y)

\begin{tabular}{|c|c|c|c|c|}
\hline Variabel & Indikator & $\begin{array}{c}\text { Koefisien } \\
\text { Korelasi }\end{array}$ & $\begin{array}{c}\text { Nilai } \\
\mathrm{r} \\
\text { Tabel }\end{array}$ & Hasil \\
\hline $\begin{array}{c}\text { Kualitas } \\
\text { Pekerjaan } \\
\text { (Y) }\end{array}$ & Y1.F1 & 1,000 & 0,404 & Valid \\
\hline
\end{tabular}

Tabel 6 merupakan hasil pengujian validitas Kualitas Pekerjaan (Y) menggunakan software SPSS. Dari data kualitas pekerjaan (Y), pertanyaan Y1.F1 diperoleh nilai koefisien korelasi lebih besar dari $r$ tabel yaitu 0,404 sehingga dapat diputuskan bahwa data terima hipotesa nol dan kesimpulannya yaitu data yang diperoleh telah valid. 


\section{2) Uji Reliabilitas}

Pengujian reliabilitas dilakukan pada 6 variabel sejenis menggunakan software SPSS dengan menggunakan rumus cronbach alpha dengan hasil sebagai berikut pada Tabel 7.

Tabel 7 Hasil Uji Reliabilitas

\begin{tabular}{|c|l|c|c|l|}
\hline Variabel & Indikator & $\begin{array}{c}\text { N on } \\
\text { Items }\end{array}$ & $\begin{array}{l}\text { Cronbach's } \\
\text { Alpha }\end{array}$ & Keterangan \\
\hline \multirow{6}{*}{$\mathrm{X}$} & Biaya & 3 & 0,810 & Reliabel \\
\cline { 2 - 5 } & Waktu & 3 & 0,842 & Reliabel \\
\cline { 2 - 5 } & $\begin{array}{l}\text { Metode } \\
\text { Pelaksanaa }\end{array}$ & 2 & 1,000 & Reliabel \\
\cline { 2 - 5 } & Kerapian & 2 & 1,000 & Reliabel \\
\cline { 2 - 5 } & $\begin{array}{l}\text { Dampak } \\
\text { Lingkungan }\end{array}$ & 3 & 0,820 & Reliabel \\
\hline Y & $\begin{array}{l}\text { Kualitas } \\
\text { Pekerjaan }\end{array}$ & 2 & 1,000 & Reliabel \\
\hline
\end{tabular}

Dari keterangan pada Tabel 7 di atas dapat diketahui bahwa masing-masing variabel memiliki Cronbach Alpha > 0,60. Dengan demikian variabel $X$ dan variabel Y dapat dikatakan reliabel.

\section{3) Uji Regresi Linier Berganda}

Dari hasil perhitungan analisis regresi linier ganda diperoleh koefisien masing-masing variabel dan dapat disusun persamaan linier berganda sebagai berikut :

$\mathrm{Y}=\mathrm{b} 0+\mathrm{b} 1 \cdot \mathrm{X} 1+\mathrm{b} 2 \cdot \mathrm{X} 2+\mathrm{b} 3 \cdot \mathrm{X} 3+\mathrm{b} 4 \cdot \mathrm{X} 4+\mathrm{b} 5 \cdot \mathrm{X} 5$

Maka persamaan tersebut menjadi :

$\mathrm{Y}=0,630+0,165 \mathrm{X} 1+0,190 \mathrm{X} 2+0,473 \mathrm{X} 3+0,173 \mathrm{X} 4+$ $0,037 \mathrm{X} 5$

Adapun interpretasi dari persamaan regresi linear berganda tersebut adalah:

- $\mathrm{a}=0,630$

Menyatakan bahwa jika X1, X2, X3, X4, dan X5 tetap (tidak mengalami perubahan) maka nilai konsistensi $\mathrm{Y}$ sebesar 0,630 .

- $\beta 1=0,165$

Koefisien regresi ini menunjukkan nilai positif yang berarti bahwa Biaya berpengaruh terhadap kualitas pekerjaan.

- $\beta 2=0,190$

Koefisien regresi ini menunjukkan nilai positif yang berarti bahwa Waktu berpengaruh terhadap kualitas pekerjaan.

- $\beta 3=0,473$

Koefisien regresi ini menunjukkan nilai positif yang berarti bahwa Metode Pelaksanaan berpengaruh terhadap kualitas pekerjaan.

- $\beta 4=0,173$

Koefisien regresi ini menunjukkan nilai positif yang berarti bahwa Kerapian berpengaruh terhadap kualitas pekerjaan.

- $\beta 5=0,037$

Koefisien regresi ini menunjukkan nilai positif yang berarti bahwa Dampak Lingkungan berpengaruh terhadap kualitas pekerjaan.

\section{4) Analisis Data}

- Uji Hipotesis Menggunakan Uji Simultas atau Uji F
Nilai Fhitung dengan menggunakan software SPSS terdapat pada Tabel 8 sebagai berikut.

Tabel 8. Nilai $\mathrm{F}_{\text {hitung }}$

\begin{tabular}{|c|c|r|r|r|c|c|}
\hline \multicolumn{2}{|c|}{ Model } & $\begin{array}{c}\text { Sum of } \\
\text { Squares }\end{array}$ & Df & $\begin{array}{c}\text { Mean } \\
\text { Square }\end{array}$ & F & Sig. \\
\hline \multirow{2}{*}{1} & Regression & 19.000 & 5 & 3.800 & 205.014 & $.000 \mathrm{~b}$ \\
\cline { 2 - 7 } & Residual & .334 & 18 & .019 & & \\
\cline { 2 - 7 } & Total & 19.333 & 23 & & & \\
\hline
\end{tabular}

Berdasarkan Tabel 8 dapat diketahui bahwa nilai $F_{\text {hitung }}$ sebesar 205.014 sedangkan nilai Ftabel dengan menggunakan taraf signifikan $5 \%$ diketahui df : $\mathrm{n}-\mathrm{k}=$ $24-5=19$ sehingga didapat nilai sebesar 2,74. Dari hasil tersebut didapatkan bahwa nilai $\mathrm{F}_{\text {hitung }}(205,014)>\mathrm{F}_{\text {tabel }}$ $(2,74)$.

Berdasarkan pada hasil tersebut dapat diambil kesimpulan bahwa hipotesa 0 dapat diterima, sehingga hipotesis "ada pengaruh variabel bebas terhadap variabel terikat" dapat diterima. Hal tersebut berarti bahwa lima variabel bebas sangat berpengaruh secara bersama - sama (Simultan) terhadap variabel terikat yaitu kualitas pekerjaan.

\section{- Uji Parsial atau Uji t}

Untuk variabel bebas terdiri dari biaya, waktu, metode pelaksanaan, kerapian, dan dampak lingkungan sedangkan untuk variabel terikat yaitu kualitas pekerjaan. Untuk hasil uji sendiri terdapat pada Tabel 9 berikut.

Tabel 9 Nilai $t_{\text {hitung }}$

\begin{tabular}{|c|l|r|r|}
\hline \multicolumn{2}{|c|}{ Model } & T & Sig. \\
\hline \multirow{1}{*}{1} & (Constant) & 2.748 & .013 \\
\cline { 2 - 4 } & X1 (Biaya) & 3.556 & .002 \\
\cline { 2 - 4 } & X2 (Waktu) & 4.051 & .001 \\
\cline { 2 - 4 } & $\begin{array}{l}\text { X3 (Metode } \\
\text { Pelaksanaan) }\end{array}$ & 4.327 & .000 \\
\cline { 2 - 4 } & X4 (Kerapian) & 2.038 & .037 \\
\cline { 2 - 4 } & $\begin{array}{l}\text { X5 (Dampak } \\
\text { Lingkungan) }\end{array}$ & .821 & .042 \\
\hline
\end{tabular}

Analisa Uji Parsial atau Uji t Variabel X1

Berdasarkan hasil dari Tabel 9 didapat nilai $t_{\text {hitung }}$ untuk variabel $\mathrm{X} 1$ yaitu 3,556, sedangkan $t_{\text {tabel }}$ dengan menggunakan $\alpha / \mathrm{k}=0,05 / 5=0,01$ diketahui df $: \mathrm{n}-\mathrm{k}-1$ $=24-5-1=18$ adalah sebesar 2,552. Berdasarkan hasil tersebut maka $t_{\text {hitung }}(3,556)>t_{\text {tabel }}(2,552)$. Berdasar pada hasil tersebut dapat diambil kesimpulan bahwa hipotesa 0 dapat diterima, sehingga hipotesis "ada pengaruh variabel biaya (X1) terhadap variabel kualitas pekerjaan (Y1)" dapat diterima. Hal tersebut berarti bahwa variabel biaya (X1) berpengaruh terhadap variabel terikat yaitu kualitas pekerjaan.

> Analisa Uji Parsial atau Uji t Variabel X2

Berdasarkan hasil dari Tabel 9 didapat nilai $t_{\text {hitung }}$ untuk variabel X2 yaitu 4,051, sedangkan $t_{\text {tabel }}$ dengan menggunakan $\alpha / \mathrm{k}=0,05 / 5=0,01$ diketahui df $: \mathrm{n}-\mathrm{k}-1$ $=24-5-1=18$ adalah sebesar 2,552. Berdasarkan hasil tersebut maka $t_{\text {hitung }}(4,051)>t_{\text {tabel }}(2,552)$. Berdasar pada 
hasil tersebut dapat diambil kesimpulan bahwa hipotesa 0 dapat diterima, sehingga hipotesis "ada pengaruh variabel waktu (X2) terhadap variabel kualitas pekerjaan (Y1)" dapat diterima. Hal tersebut berarti bahwa variabel waktu (X2) berpengaruh terhadap variabel terikat yaitu kualitas pekerjaan.

\section{> Analisa Uji Parsial atau Uji t Variabel X3}

Berdasarkan hasil dari Tabel 9 didapat nilai $t_{\text {hitung }}$ untuk variabel $\mathrm{X} 3$ yaitu 4,327 , sedangkan $\mathrm{t}_{\text {tabel }}$ dengan menggunakan $\alpha / \mathrm{k}=0,05 / 5=0,01$ diketahui df $: \mathrm{n}-\mathrm{k}-1$ $=24-5-1=18$ adalah sebesar 2,552. Berdasarkan hasil tersebut maka $t_{\text {hitung }}(4,327)>t_{\text {tabel }}(2,552)$. Berdasar pada hasil tersebut dapat diambil kesimpulan bahwa hipotesa 0 dapat diterima, sehingga hipotesis "ada pengaruh variabel metode pelaksanaan (X3) terhadap variabel kualitas pekerjaan (Y1)" dapat diterima. Hal tersebut berarti bahwa variabel metode pelaksanaan (X3) berpengaruh terhadap variabel terikat yaitu kualitas pekerjaan.

\section{$>$ Analisa Uji Parsial atau Uji t Variabel X4}

Berdasarkan hasil dari Tabel 9 didapat nilai $t_{\text {hitung }}$ untuk variabel $\mathrm{X} 4$ yaitu 2,038, sedangkan $\mathrm{t}_{\text {tabel }}$ dengan menggunakan $\alpha / \mathrm{k}=0,05 / 5=0,01$ diketahui df $: \mathrm{n}-\mathrm{k}-1$ $=24-5-1=18$ adalah sebesar 2,552. Berdasarkan hasil tersebut maka $t_{\text {hitung }}(2,038)<t_{\text {tabel }}(2,552)$. Berdasar pada hasil tersebut dapat diambil kesimpulan bahwa hipotesa 0 tidak dapat diterima, sehingga hipotesis "ada pengaruh variabel kerapian (X4) terhadap variabel kualitas pekerjaan (Y1)" tidak dapat diterima. Hal tersebut berarti bahwa variabel kerapian (X4) tidak berpengaruh terhadap variabel terikat yaitu kualitas pekerjaan.

\section{$>$ Analisa Uji Parsial atau Uji t Variabel X5}

Berdasarkan hasil dari Tabel 9 didapat nilai $t_{\text {hitung }}$ untuk variabel $\mathrm{X} 5$ yaitu 0,821 , sedangkan $\mathrm{t}_{\text {tabel }}$ dengan menggunakan $\alpha / \mathrm{k}=0,05 / 5=0,01$ diketahui df : $\mathrm{n}-\mathrm{k}-1$ $=24-5-1=18$ adalah sebesar 2,552. Berdasarkan hasil tersebut maka $t_{\text {hitung }}(0,821)<t_{\text {tabel }}(2,552)$. Berdasar pada hasil tersebut dapat diambil kesimpulan bahwa hipotesa 0 tidak dapat diterima, sehingga hipotesis "ada pengaruh variabel dampak lingkungan (X5) terhadap variabel kualitas pekerjaan (Y1)" tidak dapat diterima. Hal tersebut berarti bahwa variabel dampak lingkungan (X5) tidak berpengaruh terhadap variabel terikat yaitu kualitas pekerjaan.

\section{5) Uji Koefisien Determinasi Berganda}

Berikut hasil uji Koefisien Determinasi Berganda menggunakan software SPSS yang terdapat pada Tabel 10 Tabel 10 Model Summary

\begin{tabular}{|l|r|r|r|c|}
\hline Model & $\mathrm{R}$ & R Square & $\begin{array}{c}\text { Adjusted } \\
\text { R Square }\end{array}$ & $\begin{array}{c}\text { Std. Error } \\
\text { of the } \\
\text { Estimate }\end{array}$ \\
\hline 1 & $0,991 \mathrm{a}$ & 0,983 & 0,978 & 0,13614 \\
\hline
\end{tabular}

Dari Tabel 10 dapat diketahui hasil nilai koefisien determinasi berganda (R2) dari analisis regresi linier berganda untuk masing-masing variabel baik secara parsial maupun simultan. Nilai R Square $=0,983$ yang artinya pengaruh dari kelima variabel sebesar 98,3\% selebihnya dipengaruhi oleh variabel lain.

Berdasarkan pembahasan dari enam variabel tersebut dapat diambil kesimpulan bahwa variabel bebas berpengaruh terhadap variabel terikat dengan persentase 98,3\% selebihnya 1,7\% dipengaruhi oleh penelitian lain atau variabel lain. Sedangkan faktor yang dominan dari kelima variabel yaitu variabel metode pelaksanaan (X3) dari pada variabel lainnya.

Dari hasil uji, dengan membandingkan nilai koefsien beta masing- masing variabel dapat diketahui variabel metode pelaksanaan memiliki nilai koefisien beta terbesar yaitu 0,380. Dengan nilai koefisien beta terbesar yaitu 0,380 dapat disimpulkan bahwa variabel metode pelaksanaan memiliki pengaruh yang paling dominan terhadap kualitas pekerjaan dinding pada proyek perumahan di Kabupaten Pamekasan.

perlu.

\section{Kesimpulan dan Saran \\ 1) Kesimpulan}

Berdasarkan hasil dan pembahasan pada bab sebelumnya didapatkan kesimpulan sebagai berikut.

- $\quad$ Kelima variabel berpengaruh terhadap variabel (Y) yaitu kualitas pekerjaan. Kualitas bata ringan lebih bagus digunakan pada pasangan dinding pembangunan perumahan dari pada penggunaan bata merah.

- Faktor yang paling dominan pengaruhnya dalam pekerjaan dinding terhadap pembangunan perumahan type 46 di Pamekasan adalah metode pelaksanaan dengan nilai beta sebesar 0,380.

\section{2) Saran}

- Dalam penelitian ini hanya menggunakan 5 variabel yaitu biaya, waktu, metode pelaksanaan, kerapian, dan dampak lingkungan. Untuk penelitian selanjutnya, perlu menambahkan variabel lain yang tidak masuk dalam penelitian ini.

- Disarankan penggunaan bata ringan pada pembangunan perumahan type 46.

- Penelitian lanjutan terkait perbandingan teknis metode pekerjaan terhadap penggunaan bata ringan dan bata merah.

\section{Daftar Pustaka}

Abdurrohmansyah, Adha, I., dan Ali, H. 2015. Studi Kuat Tekan Batu Bata Menggunakan Bahan Additive Berdasarkan Spesifikasi Standar Nasional Indonesia (SNI). JRSDD, 3(3): 541-552.

Aditha, M. 2010. Perhitungan Harga Satuan Dinding Bata Ringan dengan metode SNI dan Ms. Project pada Proyek Gedung Laboratorium Terpadu Universitas Brawijaya. Skripsi. Universitas Brawijaya. Malang.

Dharmayanti, G.A.P Candra, Sudipta, I. Gusti Ketut, dan Saputra, G. Tusan. 2016. Analisis Perbandingan Biaya dan Waktu Pekerjaan Dinding Menggunakan Bata Merah Dengan M-Panel. Jurnal Ilmiah Teknik Sipil, 20(2): 119-126.

Manto, J. 2012. Mengidentifikasi Durasi dan Tenaga Kerja Berdasarkan Analisa Harga Satuan Pekerjaan (AHSP) pada Perncanaan Villa Damai. Skripsi. Sekolah Tinggi Teknik Bina Taruna Gorontalo. Gorontalo. 
Nazir, M. 1983. Metode Penelitian. Ghalia Indonesia. Jakarta.

Rahman, A. 2011. Perbandingan Estimasi Biaya Metode SNI dan BOW pada Proyek Pembangunan Gedung Joang. Skripsi. Universitas 17 Agustus 1945 Samarinda. Samarinda.

Santoso, S. 2006. Menguasai statistic di era informasi dengan SPSS 14. PT Elex Media Komputindo. Jakarta.

SNI 15-2094-2000. Bata Merah Pejal untuk Pasangan Dinding.

SNI 03-0349-1989. Bata Beton Untuk Pasangan Dinding. Susanto, D. Oni, Nurcahyo, C. Bintang, dan Putri, Y. Eka. 2014. Perbandingan Penggunaan Material Batu Bata Merah dengan Bata Ringan I-CON akibat Perubahan Desain Struktur Ditinjau dari Biaya dan Waktu : Studi Kasus Gedung Rektorat dan IT Universitas Negeri Surabaya. Jurnal Teknik Pomits, 3(2): 1-7.

Sugiyono. 2002. Metodologi Penelitian Administrasi. Bandung : Alfabeta

Walpole, Ronald E. 1995. Pengantar Statistik. Edisi ke3. Jakarta: PT. Gramedi Pustaka Utama

Wahyuningsih, S. 2018. Motivasi Tenaga Kerja Wanita Bekerja Di Bidang Proyek Konstruksi. Skripsi. Universitas Madura Pamekasan. 


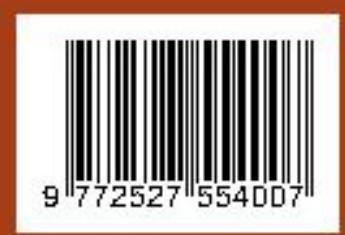

